Prepared in cooperation with the National Park Service

\title{
Delineation of Flood-Inundation Areas in Grapevine Canyon Near Scotty's Castle, Death Valley National Park, California
}

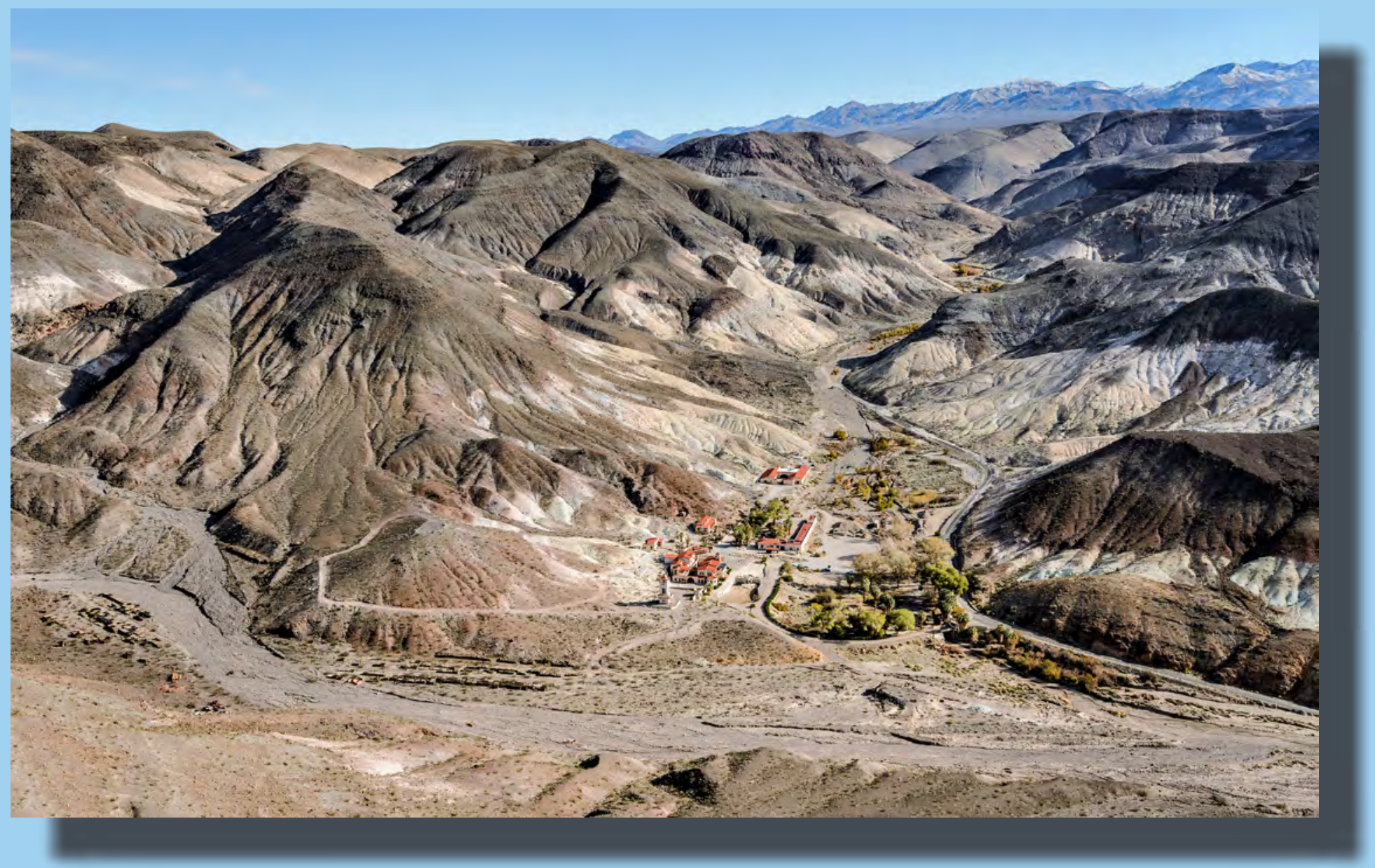

Scientific Investigations Report 2020-5082 
Cover photo: Looking upstream from Tie and Grapevine Canyon confluence at Scotty's Castle, Death Valley National Park. Photograph taken by Neal Nurmi, National Park Service, on November 27, 2015. 


\section{Delineation of Flood-Inundation Areas in Grapevine Canyon Near Scotty's Castle, Death Valley National Park, California}

By Christopher M. Morris, Toby L. Welborn, and J. Toby Minear

Prepared in cooperation with the National Park Service

Scientific Investigations Report 2020-5082 


\title{
U.S. Department of the Interior \\ DAVID BERNHARDT, Secretary
}

\author{
U.S. Geological Survey \\ James F. Reilly II, Director
}

U.S. Geological Survey, Reston, Virginia: 2020

For more information on the USGS - the Federal source for science about the Earth, its natural and living resources, natural hazards, and the environment-visit https://www.usgs.gov or call 1-888-ASK-USGS.

For an overview of USGS information products, including maps, imagery, and publications, visit https://store.usgs.gov/.

Any use of trade, firm, or product names is for descriptive purposes only and does not imply endorsement by the U.S. Government.

Although this information product, for the most part, is in the public domain, it also may contain copyrighted materials as noted in the text. Permission to reproduce copyrighted items must be secured from the copyright owner.

Suggested citation:

Morris, C.M., Welborn, T.L., and Minear, J.T., 2020, Delineation of flood-inundation areas in Grapevine Canyon near Scotty's Castle, Death Valley National Park, California: U.S. Geological Survey Scientific Investigations Report 2020-5082, 27 p., https://doi.org/10.3133/sir20205082.

Associated data for this publication:

Morris, C.M., Welborn, T.L., and Minear, J.T., 2020, Geospatial Data: California, Tabular Data, and Surface-Water Model Archive for Delineation of Flood-Inundation Areas in Grapevine Canyon Near Scotty's Castle, Death Valley National Park, https://doi.org/10.5066/P9IPKW55.

ISSN 2328-0328 (online) 


\section{Contents}

Abstract

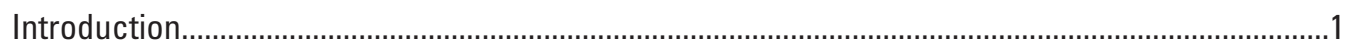

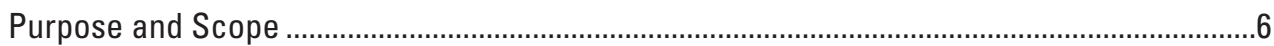

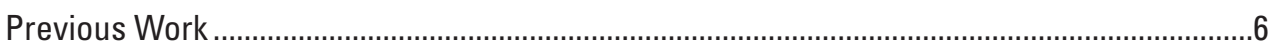

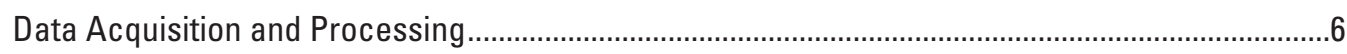

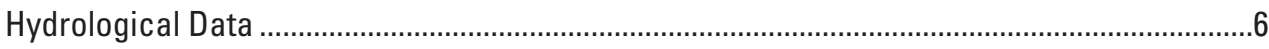

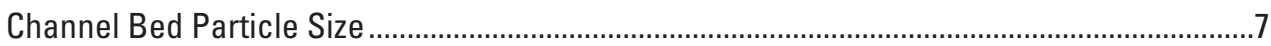

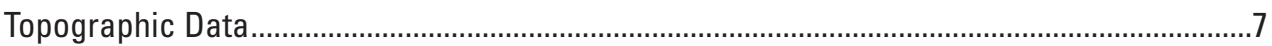

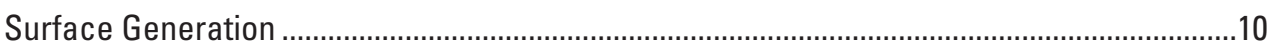

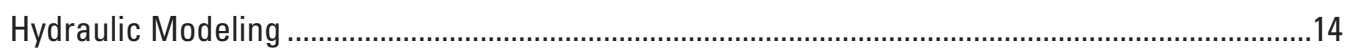

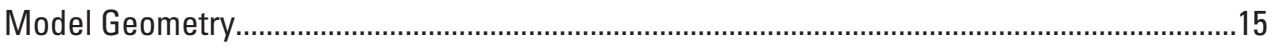

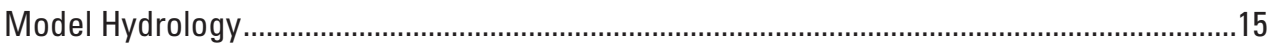

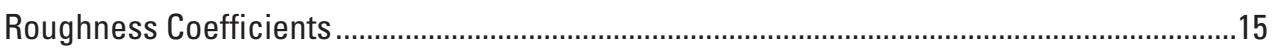

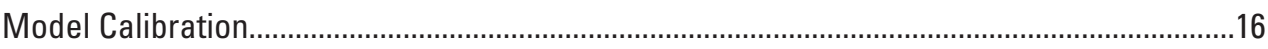

Sensitivity Analysis ...........................................................................................................

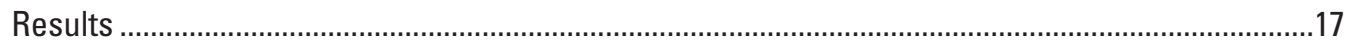

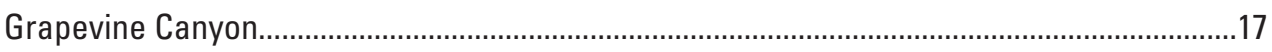

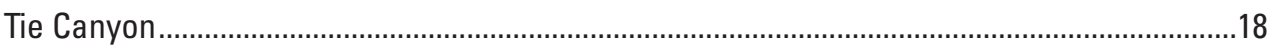

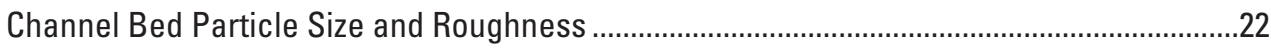

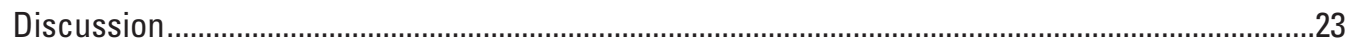

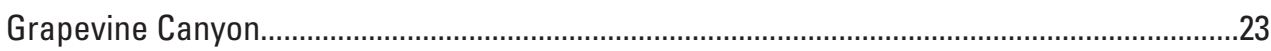

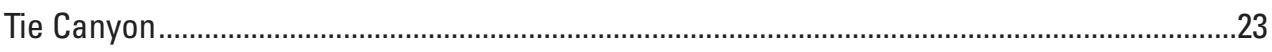

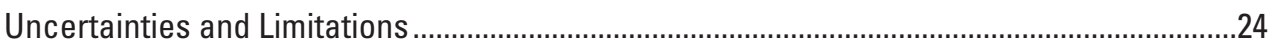

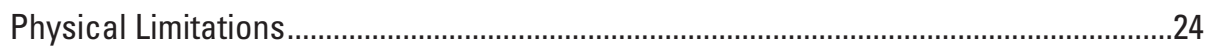

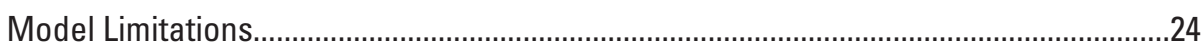

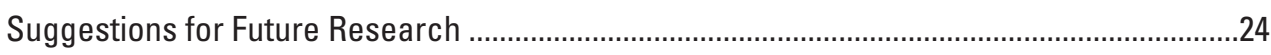

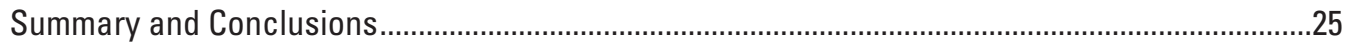

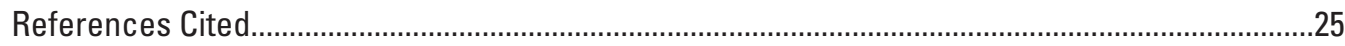

\section{Figures}

1. Map showing location of Scotty's Castle in Grapevine Canyon, Death Valley National Park, California and Nevada .........................................................................

2. Map showing study area extent and model reaches of Scotty's Castle in Grapevine Canyon, Death Valley National Park, California ...............................................

3. Aerial photographs from before and after the October 18, 2015, flood of Scotty's Castle in Grapevine Canyon, Death Valley National Park, California ................................4

4. Images of flood damage from the October 18, 2015, flood of Scotty's Castle in Grapevine Canyon, Death Valley National Park, California

5. Map showing pebble count, terrestrial laser scanner, single-baseline static survey observation locations for Scotty's Castle in Grapevine Canyon, Death Valley National Park, California. 
6. Map showing terrestrial laser scanner minimum elevation filtering areas used to create the digital terrain model for Scotty's Castle in Grapevine Canyon,

Death Valley National Park, California

7. Map showing digital terrain model for Scotty's Castle in Grapevine Canyon, Death Valley National Park, California.

8. Map showing spatial distribution of measured residual error between ground control points and the digital terrain model for Scotty's Castle in Grapevine Canyon, Death Valley National Park, California.

9. Histogram and cumulative percentage of residual error between ground control points and the digital terrain model for Scotty's Castle in Grapevine Canyon, Death Valley National Park, California..

10. Graph showing surveyed versus modeled water surface for October 18, 2015, flood at Scotty's Castle in Grapevine Canyon, Death Valley National Park, California

11. Map showing flood-inundation areas for the 4-percent annual exceedance probability flood streamflow for Scotty's Castle in Grapevine Canyon, Death Valley National Park, California

12. Map showing flood-inundation areas for the 2-percent annual exceedance probability flood streamflow for Scotty's Castle in Grapevine Canyon, Death Valley National Park, California.

13. Map showing flood-inundation areas for the 1-percent annual exceedance probability flood streamflow for Scotty's Castle in Grapevine Canyon, Death Valley National Park, California.

14. Map showing flood-inundation areas for the 0.5 -percent annual exceedance probability flood streamflow for Scotty's Castle in Grapevine Canyon, Death Valley National Park, California

15. Map showing flood-inundation areas for the 0.2-percent annual exceedance probability flood streamflow for Scotty's Castle in Grapevine Canyon, Death Valley National Park, California.

\section{Tables}

1. Historic flood streamflow measurements made in Grapevine Canyon, Death Valley National Park, California

2. Drainage areas and percent annual exceedance probability streamflows for select locations in Grapevine Canyon, Death Valley National Park, California

3. Results of single-baseline static surveys for Scotty's Castle in Grapevine Canyon, Death Valley National Park, California.

4. Error assessment for maximum errors in terrestrial laser scanning data for Scotty's Castle in Grapevine Canyon, Death Valley National Park, California

5. Results of pebble counts and computed $n$-values for Scotty's Castle in Grapevine and Tie Canyons, Death Valley National Park, California 


\section{Conversion Factors}

U.S. customary units to International System of Units

\begin{tabular}{|c|c|c|}
\hline Multiply & By & To obtain \\
\hline \multicolumn{3}{|c|}{ Length } \\
\hline inch (in.) & 2.54 & centimeter $(\mathrm{cm})$ \\
\hline inch (in.) & 25.4 & millimeter $(\mathrm{mm})$ \\
\hline foot (ft) & 0.3048 & meter $(\mathrm{m})$ \\
\hline mile (mi) & 1.609 & kilometer $(\mathrm{km})$ \\
\hline \multicolumn{3}{|c|}{ Area } \\
\hline square mile $\left(\mathrm{mi}^{2}\right)$ & 259.0 & hectare (ha) \\
\hline square mile $\left(\mathrm{mi}^{2}\right)$ & 2.590 & square kilometer $\left(\mathrm{km}^{2}\right)$ \\
\hline \multicolumn{3}{|c|}{ Volume } \\
\hline cubic foot $\left(\mathrm{ft}^{3}\right)$ & 0.02832 & cubic meter $\left(\mathrm{m}^{3}\right)$ \\
\hline \multicolumn{3}{|c|}{ Flow rate } \\
\hline foot per second (ft/s) & 0.3048 & meter per second $(\mathrm{m} / \mathrm{s})$ \\
\hline cubic foot per second ( $\mathrm{ft} 3 / \mathrm{s})$ & 0.02832 & cubic meter per second $\left(\mathrm{m}^{3} / \mathrm{s}\right)$ \\
\hline
\end{tabular}

International System of Units to U.S. customary units

\begin{tabular}{lll}
\hline \multicolumn{1}{c}{ Multiply } & \multicolumn{1}{c}{ By } & \multicolumn{1}{c}{ To obtain } \\
\hline millimeter $(\mathrm{mm})$ & Length & \\
meter $(\mathrm{m})$ & 0.03937 & inch (in.) \\
& 3.281 & foot $(\mathrm{ft})$ \\
\hline square meter $\left(\mathrm{m}^{2}\right)$ & Area & \\
\hline
\end{tabular}

\section{Datum}

Vertical coordinate information is referenced to the North American Vertical Datum of 1988 (NAVD 88).

Horizontal coordinate information is referenced to the North American Datum of 1983 (NAD 83).

Elevation, as used in this report, refers to distance above the vertical datum. 


\section{Abbreviations}

$\begin{array}{ll}\text { AEP } & \text { annual exceedance probability } \\ \text { DTM } & \text { digital terrain model } \\ \text { FHWA } & \text { Federal Highway Administration } \\ \text { GCP } & \text { ground control points } \\ \text { GNSS } & \text { Global Navigation Satellite System } \\ \text { HEC-RAS } & \text { Hydrologic Engineering Center-River Analysis System } \\ \text { lidar } & \text { light imaging, detection, and ranging } \\ \text { NPS } & \text { National Park Service } \\ \text { OPUS-S } & \text { Online Positioning User Service-Static } \\ \text { RMS } & \text { root mean square error } \\ \text { RTK } & \text { real-time kinematic } \\ \text { TIN } & \text { triangulated irregular network } \\ \text { TLS } & \text { terrestrial laser scanner } \\ \text { USGS } & \text { U.S. Geological Survey }\end{array}$




\title{
Delineation of Flood-Inundation Areas in Grapevine Canyon Near Scotty's Castle, Death Valley National Park, California
}

\author{
By Christopher M. Morris, Toby L. Welborn, and J. Toby Minear
}

\section{Abstract}

On October 18, 2015, a large flood caused considerable damage in Grapevine Canyon near Death Valley Scotty Historic District, in Death Valley National Park, California. Significant channel changes had limited the applicability of previously created flood-inundation maps to current conditions. Predicted flood-inundation maps for Scotty's Castle were updated using one-dimensional hydraulic models. A digital terrain model was created for the study area using a terrestrial laser scanner for use in the hydraulic models. Estimations of the 4, 2, 1, 0.5, and 0.2-percent annual exceedance probability flood streamflows (previously known as the $25,50,100,250$, and 500-year floods) were computed from regional flood regression equations. The estimated flood streamflows were used with the hydraulic models to compute water surface elevations that were mapped on the digital terrain model. The results indicate inundation of the visitor center and park offices occurs by the 4-percent annual exceedance probability flood. Bridge and embankment overtopping occurs by the 2-percent annual exceedance probability flood. Sections of Grapevine Canyon Road and the parking lot are inundated by the 4-percent annual exceedance probability flood and above streamflows. None of the computed streamflows reach Scotty's Castle main building.

\section{Introduction}

Death Valley Scotty Historic District (hereafter referred to as Scotty's Castle) is in the northeast part of Death Valley National Park, in Grapevine Canyon, adjacent to the confluence with Tie Canyon. Grapevine Canyon drains the steep western slopes of the Grapevine Mountains near the Nevada and California State line (fig. 1) with a drainage area of approximately 47.9 square miles $\left(\mathrm{mi}^{2}\right)$. Tie Canyon makes up the northwestern part of the Grapevine Canyon Basin and has a drainage area of approximately $20.5 \mathrm{mi}^{2}$. Elevations in the Grapevine Canyon Basin range from 7,008 feet (ft) in the Grapevine Mountains to 2,300 $\mathrm{ft}$ at the canyon mouth, with an average slope of 17.6 percent. Both Grapevine and Tie Canyons have very steep channels (0.04 and 0.06, respectively). At its confluence with Grapevine Canyon, the Tie Canyon channel becomes a narrow alluvial fan with two main and several smaller distributary channels (fig. 2).

Several small springs provide perennial streamflow over short distances, but otherwise both Grapevine and Tie Canyons are dry, with streamflow only occurring for short durations as a result of heavy rainfall. Such rainfall induced streamflows are flashy, with drastic changes in streamflow over short periods of time. Both Grapevine and Tie Canyon have been gaged since December 2016. In areas with perennial streamflow, or shallow groundwater, very dense thickets of willow (Salix sp.), Fremont cottonwood (Populus fremontii), three-square bulrush (Schoenoplectus americanus), mesquite (Prosopis sp.), saltgrass (Distichlis spicata), desert wild grapevine (Vitis girdiana), and other riparian vegetation grow. Elsewhere, the active channel is mostly bare, with a gravel and cobble channel bed. In wider sections of the canyon, moderately dense saltbush (Atriplex sp.) and rabbitbrush (Ericameria sp.) grow on small alluvial terraces with vertical cut banks at the active channel. Elsewhere, colluvium slopes, alluvial fans, or bedrock directly border the active channel. Canyon slopes are either bedrock or have thin soils of gravel with sparse creosote (Larrea tridentata) and bursage (Ambrosia dumosa) shrubs.

Scotty's Castle is a popular tourist attraction on the National Register of Historic Places (National Park Service, 2016). The area includes several historically and architecturally significant buildings, park administration facilities, parking lots, and public water supply and utility infrastructure (fig. 2). Access to Scotty's Castle is limited to the paved Grapevine Canyon Road that passes along the entire length of Grapevine Canyon and, in some locations, takes up the entire width of the canyon floor. 


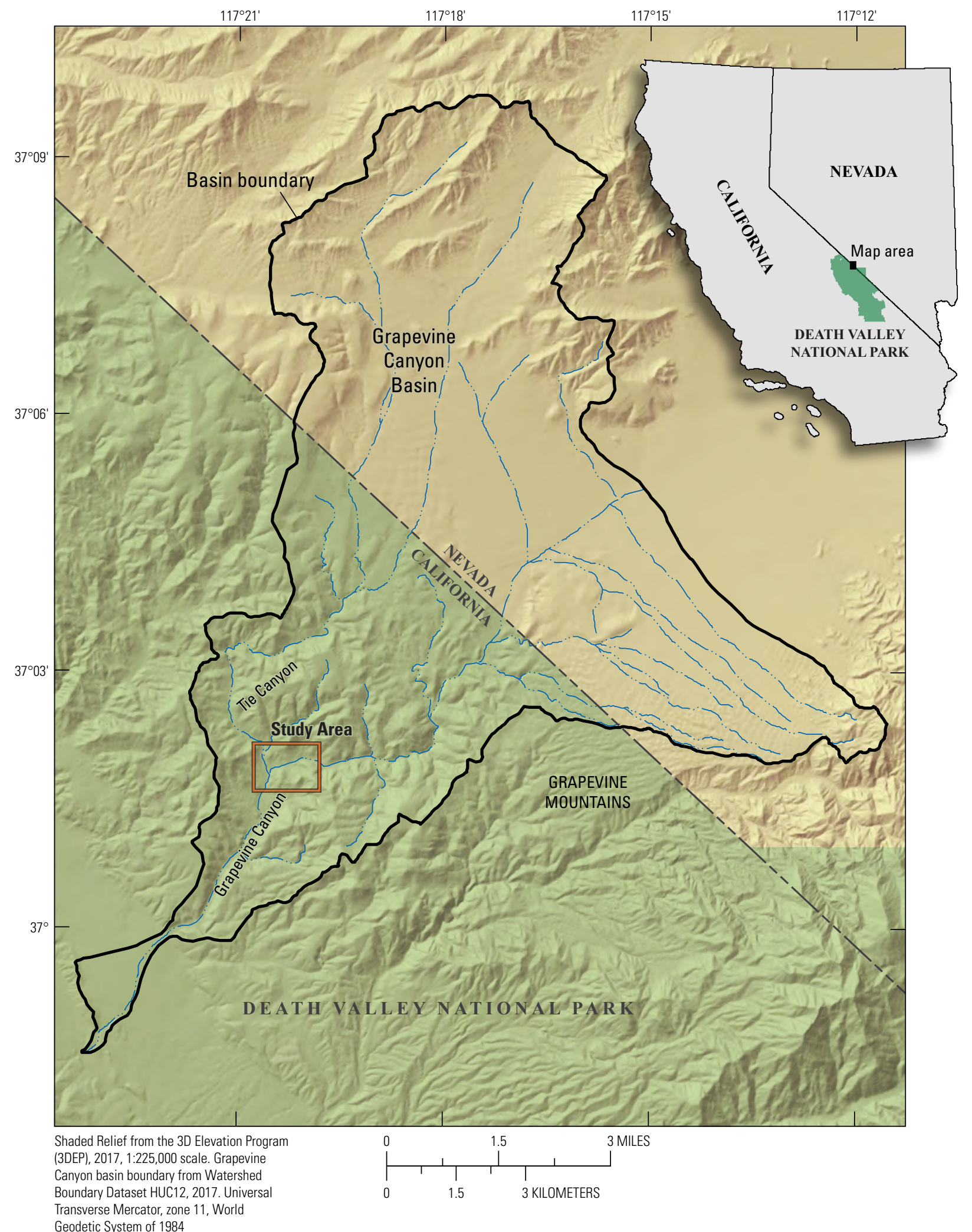

Figure 1. Location of Scotty's Castle in Grapevine Canyon, Death Valley National Park, California and Nevada. 


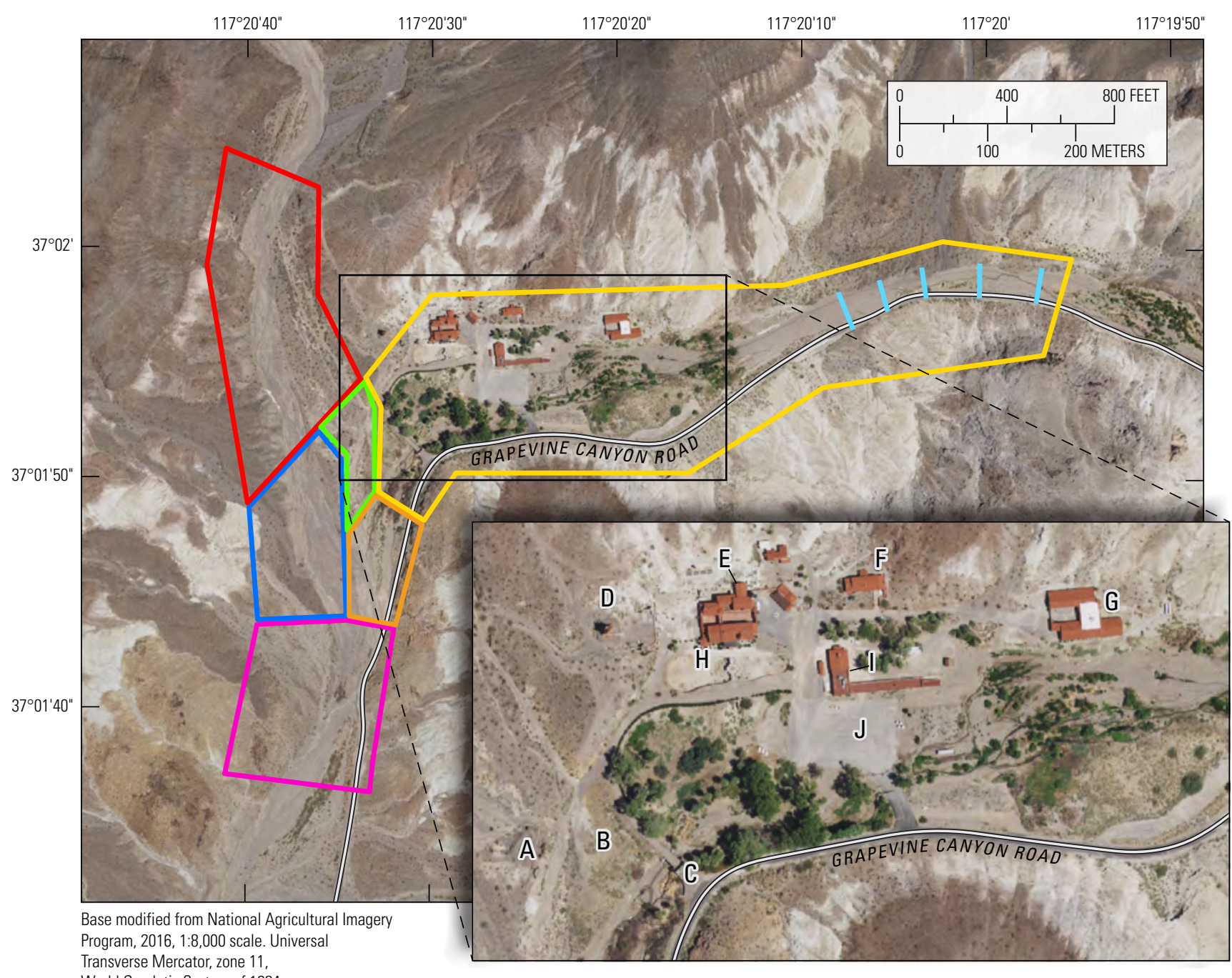

\section{EXPLANATION}

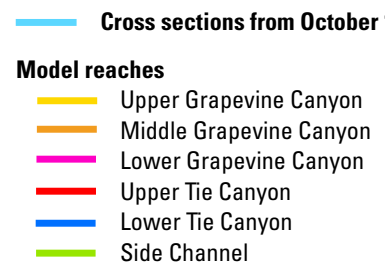

$\begin{array}{ll}\text { Buildings and structures } & \\ \text { A Gravel separator } & \text { F Hacienda } \\ \text { B Overflow parking lot } & \text { G Stable } \\ \text { C Castle Gate Bridge } & \text { H Pools } \\ \text { D Chimes Tower } & \text { I Visitors center and park offices } \\ \text { E Scotty's Castle } & \text { J Main parking lot }\end{array}$

Figure 2. Study area extent and model reaches of Scotty's Castle in Grapevine Canyon, Death Valley National Park, California.

On October 18, 2015, an intense, nearly stationary thunderstorm triggered flooding in Grapevine and Tie Canyons (National Weather Service, 2015). A rain gage at Scotty's Castle recorded 2.72 inches of precipitation over a 5 -hour period, and information from weather radar suggested 3-4 inches of precipitation in the lower part of the drainage basin during the same event (National Weather Service, 2015). Grapevine Canyon Road, power and water infrastructure, and several buildings at Scotty's Castle were damaged by the flood water and debris, necessitating closure of the area to the public. As a result of the flood, mud, gravel, cobble, and boulders were deposited inside and outside of several historic and park administration buildings, damaging walls and breaking windows and doors. The visitor center parking lot, within the active channel, had sediment deposits several feet deep (fig. 3). The spring house and water pipeline transporting water to Scotty's Castle from a spring upstream were heavily damaged. Twenty power poles and over 1 mile of fencing were destroyed (fig. 4). Five to ten feet of channel incision occurred in Grapevine Canyon from near the confluence with Tie Canyon through Castle Gate Bridge (hereafter referred to as the bridge) to the picnic area next to the parking lot (fig. 2). 

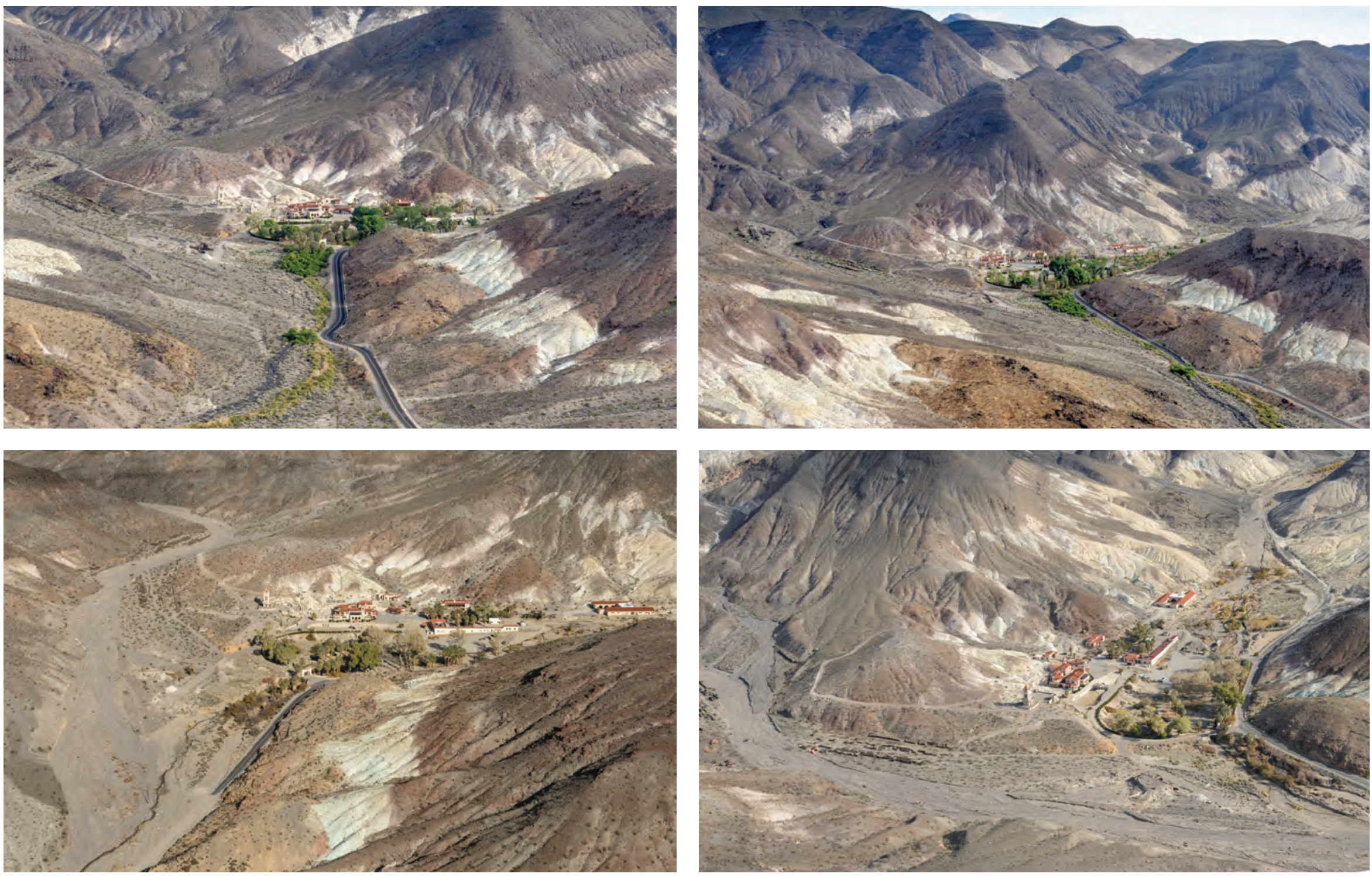

Figure 3. Aerial photographs from before and after the October 18, 2015, flood of Scotty's Castle in Grapevine Canyon, Death Valley National Park, California. Photographs (top) taken on March 21, 2015, looking upstream from downstream end of the modeled reach. Photographs by Birgitta Jansen, National Park Service. Photographs (bottom) taken on November 27, 2015, looking upstream from Tie and Grapevine Canyon confluence. Photographs by Neal Nurmi, National Park Service. 

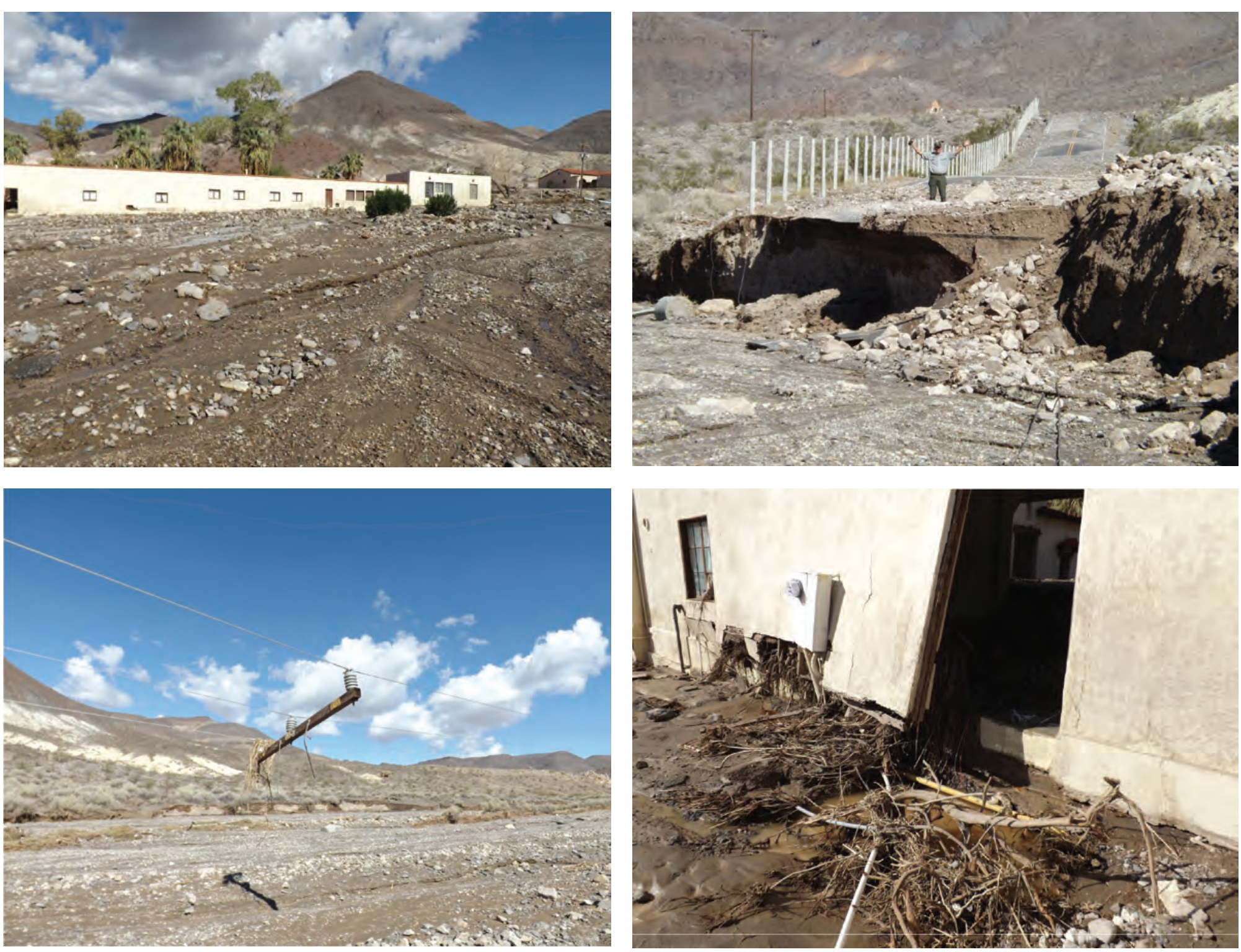

Figure 4. Images of flood damage from the October 18, 2015, flood of Scotty's Castle in Grapevine Canyon, Death Valley National Park, California. From upper left clockwise: visitor center and park offices, road damage downstream of modeled reach, visitor center and park offices, damaged power pole. Photographs by National Park Service. 
A large percentage of vegetation in Grapevine Canyon was removed, leaving bare channels in areas that had previously been dense shrubs. Finally, sections of the Grapevine Canyon Road were either completely removed by the flood waters or heavily damaged (fig. 4; Josh Hoines, National Park Service, oral commun., 2017).

In additional to the main channel streamflow in Grapevine and Tie Canyons, streamflow also occurred in gullies and on hillslopes. At Scotty's Castle, many natural gullies end at pavement or at the walls of buildings, resulting in additional damage and debris deposits.

The area is expected to be closed to the public until at least 2020 and cost $\$ 50$ million to repair (National Park Service, 2016).

At Scotty's Castle, flood waters from the October 18 flood rose to the 1-percent annual exceedance probability (AEP) flood water level delineated from a flood-inundation map for the area (Bowers, 1989), with an estimated streamflow of 12,000 cubic feet per second (cfs). However, a post-flood streamflow measurement using surveyed high-water marks, cross sections, roughness, and other channel characteristics (hereafter referred to as an indirect measurement) made approximately 2,000 ft upstream of Scotty's Castle computed a streamflow of only $3,200 \mathrm{cfs}$.

The difference in streamflow between the indirect measurement and the estimated streamflow from Bowers (1989) suggests that the previous flood-inundation mapping is no longer applicable, and a new analysis, based on current (2016) conditions, is needed to document current channel conditions.

\section{Purpose and Scope}

This report describes and documents the field data collection and development of a one-dimensional model to map the 4, 2, 1, 0.5, and 0.2-percent AEP flood-inundation areas near Scotty's Castle. The model extent is from about $1,300 \mathrm{ft}$ downstream from the confluence of Grapevine and Tie Canyons to about 3,500 ft upstream in Grapevine Canyon, and to about 2,200 ft upstream in Tie Canyon (fig. 2). All spatial data and models are published in Morris and others (2020).

\section{Previous Work}

Steep slopes, shallow soils, limited vegetation, and potential for intense rainfall make flash floods a common occurrence in Death Valley. Peak streamflows were monitored at seven sites in the current Death Valley National Park boundaries by the U.S. Geological Survey (USGS) from the late 1950s to the mid-1970s in association with a California statewide monitoring program of floods in small drainages (Waananen, 1971). Only two of these sites continued to be monitored past 1974, and peak streamflow monitoring at both of those ended by 1989 (US. Geological Survey, 2018a, 2018b). Miller (1977) provided some additional discrete measurements and descriptions of several flood events, including an indirect measurement of a $727 \mathrm{cfs}$ flood from July 1968 at the mouth of Grapevine Canyon.

Several USGS studies have examined and mapped flood-inundation areas at Furnace Creek (Crippen, 1979), Wildrose Canyon (Crippen, 1981), and Grapevine Canyon (Bowers, 1989) in Death Valley National Park. In 1983, the National Park Service (NPS) completed a more geographically diverse analysis of flooding using single channel cross-sections near major infrastructure (Overzet and others, 1983). These studies computed supercritical, high velocity streamflow with the possibility of dramatic changes in hydraulics during floods because of possible erosion, transportation, and deposition of large amounts of debris and sediment. The lack of long-term data for flood frequency analyses has also been noted as an additional uncertainty.

Flood-inundation areas in Grapevine and Tie Canyons (including Scotty's Castle) were mapped after the July 1976 flood by Bowers (1989). Eighteen cross sections were surveyed along the entire length of Grapevine Canyon and the downstream end of Tie Canyon. Step-backwater (Chow, 1959) and slope-conveyance methods were used to compute the water surface elevations for the 4, 2, and 1-percent AEP floods as computed from regional regression equations. The computed AEP water surfaces were delineated using an existing 1972 topographic map. Since Grapevine Canyon and Tie Canyon were ungaged, no model calibration or verification was completed. However, the area delineated for the 4-percent AEP flood (3,500 cfs) was generally verified by an estimated streamflow of 2,900 cfs from the July 1976 flood, which was calculated based on depth and width observations made by the NPS. The July 1976 flood reportedly incised a channel into the parking lot (Bowers, 1989).

\section{Data Acquisition and Processing}

The hydraulic model used required topographic and streamflow data. Topographic data were surveyed using a terrestrial laser scanner. In the absence of streamflow data, regional regression models were used to estimate streamflow for 4, 2, 1, 0.5, and 0.2-percent AEP floods.

\section{Hydrological Data}

Floods can be described based their frequency of occurrence. The AEP of a flood is the likelihood of a given streamflow occurring or being exceeded in any given year. The 1-percent AEP has a 1 in 100 chance to occur or be exceeded in any given year. Although a 1-percent AEP is colloquially known as the "100-year flood," this terminology is misleading because the flood may not occur every 100 years (Holmes and Dinicola, 2010). 
With only three flood streamflow measurements made in Grapevine Canyon (table 1), the data requirements for a flood frequency analysis as described in Bulletin 17C (England and others, 2018) are not met. Therefore, regional regression equations from Gotvald and others (2012) were used to estimate the streamflow for $4,2,1,0.5$, and 0.2-percent AEP floods at three ungaged locations using the following equations:

$$
\begin{gathered}
Q_{4}=403 A^{0.506} \\
Q_{2}=760 A^{0.506} \\
Q_{1}=1350 A^{0.506} \\
Q_{0.5}=2270 A^{0.506} \\
Q_{0.2}=4280 A^{0.506}
\end{gathered}
$$

where $Q_{n}$ is the AEP streamflow in cfs and $A$ is the drainage basin area in square miles.

The regional regression equation estimates for Grapevine Canyon Bridge, Tie Canyon, and Lower Grapevine Canyon are presented in table 2 .

\section{Channel Bed Particle Size}

The composition of the streambed and banks influences channel form and hydraulics. To gain a better understanding of the composition of the study area, a total of five Wolman-style pebble counts were performed in the channel to determine the size of the channel bed particles (Wolman, 1954) and help evaluate channel roughness used in the models. A $30 \mathrm{ft}$ by $30 \mathrm{ft}$ square was established, and 100 particles were selected

Table 1. Historic flood streamflow measurements made in Grapevine Canyon, Death Valley National Park, California.

[cfs, cubic foot per second; $\mathrm{ft}$, foot]

\begin{tabular}{lccc}
\hline \multicolumn{1}{c}{ Date } & \multicolumn{1}{c}{ Location } & $\begin{array}{c}\text { Streamflow } \\
\text { (cfs) }\end{array}$ & \multicolumn{1}{c}{ Type } \\
\hline July 28, 1968 & $\begin{array}{c}\text { 15,000 ft downstream } \\
\text { of Scotty's Castle }\end{array}$ & 727 & Slope area \\
July 1976 & $\begin{array}{l}\text { Scotty's Castle } \\
\text { October 18, 2015 }\end{array}$ & 2,900 & Estimate \\
& $\begin{array}{c}\text { 2,000 ft upstream of } \\
\text { Scotty's Castle }\end{array}$ & 3,200 & Slope area \\
\hline
\end{tabular}

randomly every $3 \mathrm{ft}$ by $3 \mathrm{ft}$ in a grid pattern. The intermediate axis was measured using a gravelometer and tallied. Pebble counts were made at an overbank location and active channel location in Grapevine and Tie Canyons and an active channel location at their confluence (fig. 5). The pebble count locations were selected to be representative of the channels.

\section{Topographic Data}

Terrestrial laser scanner (TLS) and Global Navigation Satellite System (GNSS) surveys were completed at Scotty's Castle from July 12-14, 2016, to collect present-day, high-resolution topography data for the one-dimensional modeling. The GNSS surveys consisted of single-baseline Online Positioning User Service-Static (OPUS-S) surveys at four locations for survey control and single-base, real-time kinematic (RTK) GNSS surveys. The RTK surveys collected observations at TLS scan origins, survey control, back-sights, and ground control points (GCP). The GCP were used for an independent quality check of the TLS-derived digital terrain model (DTM).

No published benchmark data were found for the study area. Because of this, single-baseline OPUS-S surveys were completed at three Federal Highway Administration (FHWA) benchmarks and one temporary reference point, Rebar1, in the Scotty's Castle area (fig. 5). Static observations were collected using Topcon GR-3 and Leica Viva GS14 GNSS receivers on 2-meter fixed height tripods. Processing of static observations was done using the National Geodetic Survey Online Positioning User System (OPUS). Single-baseline static survey level quality, occupation times, observations used, ambiguities, solution root mean square error (RMS), and vertical peak-to-peak are presented in table 3. Known errors affecting the single-baseline OPUS-S surveys included a battery failure at FHWA-3511 on July 12, 2016, and a failed data collection at Rebar1 on July 13, 2016, resulting in a single observation on the benchmark.

Table 2. Drainage areas and percent annual exceedance probability streamflows for select locations in Grapevine Canyon, Death Valley National Park, California.

[Based on regional regression equations from Gotvald and others, 2012]

\begin{tabular}{lcccccc}
\hline Location & $\begin{array}{c}\text { Area } \\
\text { (square }\end{array}$ & \multicolumn{4}{c}{$\begin{array}{c}\text { Percent AEP streamflow } \\
\text { (cubic feet per second) }\end{array}$} \\
\cline { 3 - 7 } miles) & $\mathbf{4}$ & $\mathbf{2}$ & $\mathbf{1}$ & $\mathbf{0 . 5}$ & $\mathbf{0 . 2}$ \\
\hline Tie Canyon & 20.5 & 1,860 & 3,510 & 6,230 & 10,500 & 19,700 \\
$\begin{array}{c}\text { Grapevine } \\
\text { Canyon Bridge }\end{array}$ & 24.4 & 2,030 & 3,830 & 6,800 & 11,400 & 21,600 \\
$\begin{array}{c}\text { Lower Grapevine } \\
\text { Canyon }\end{array}$ & 44.9 & 3,890 & 7,340 & 13,030 & 21,900 & 41,300 \\
\hline
\end{tabular}




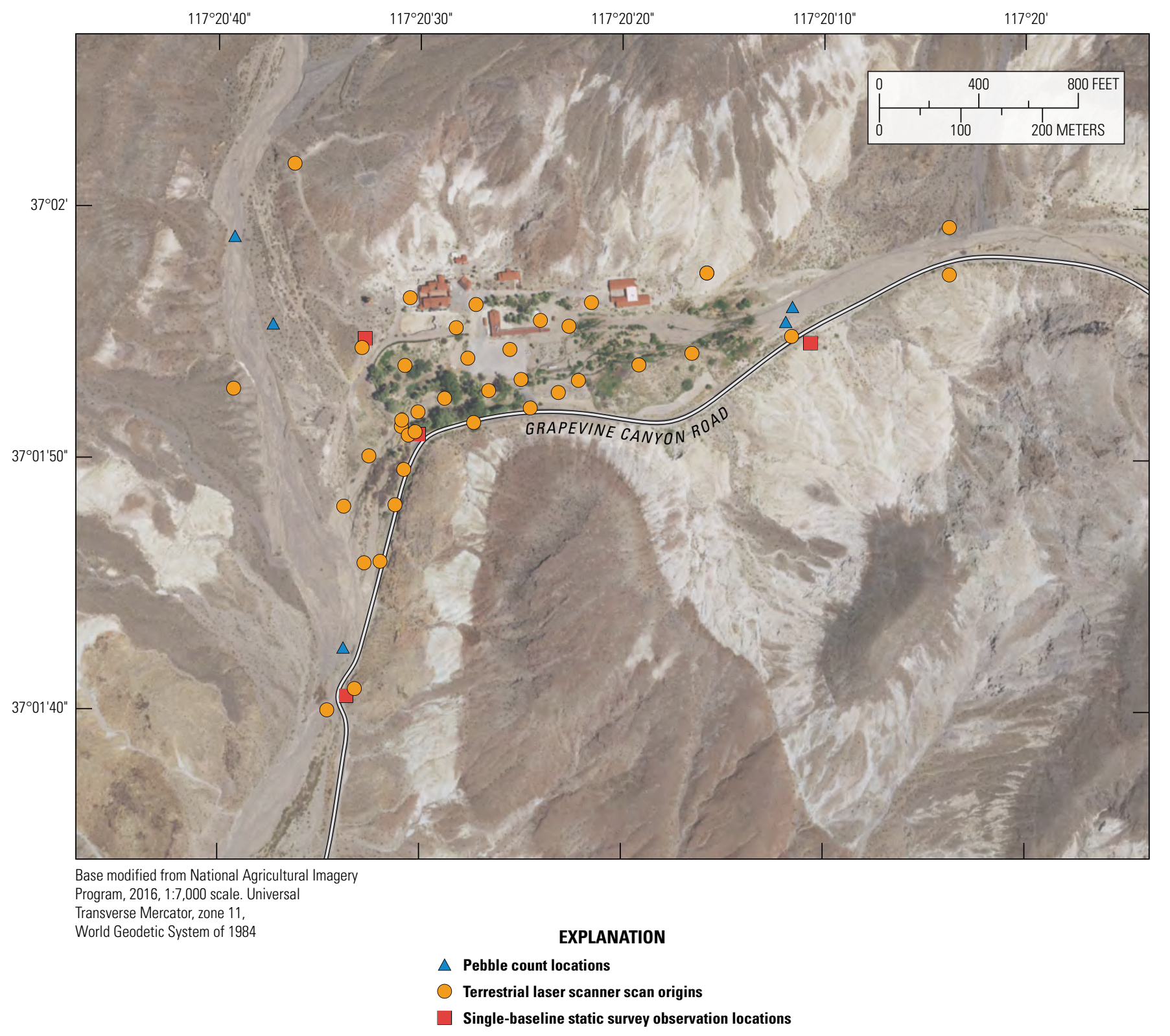

Figure 5. Pebble count, terrestrial laser scanner, single-baseline static survey observation locations for Scotty's Castle in Grapevine Canyon, Death Valley National Park, California.

Table 3. Results of single-baseline static surveys for Scotty's Castle in Grapevine Canyon, Death Valley National Park, California. [hh:mm, hour:minute; mm/dd/yyyy, month/day/year; RMS, root mean square error]

\begin{tabular}{|c|c|c|c|c|c|c|c|}
\hline Benchmark & $\begin{array}{c}\text { Date } \\
\text { (mm/dd/yyyy) }\end{array}$ & $\begin{array}{l}\text { Level } \\
\text { quality }\end{array}$ & $\begin{array}{c}\text { Occupation time } \\
\text { (hh:mm) }\end{array}$ & $\begin{array}{c}\text { Observations used } \\
\text { (percent) }\end{array}$ & $\begin{array}{c}\text { Fixed ambiguities } \\
\text { (percent) }\end{array}$ & $\begin{array}{c}\text { RMS error } \\
\text { (meters) }\end{array}$ & $\begin{array}{c}\text { Vertical peak to peak } \\
\text { (meters) }\end{array}$ \\
\hline \multirow[t]{2}{*}{ FHWA3510 } & $07 / 12 / 2016$ & Level II & 03:54 & 96 & 94 & 0.011 & 0.038 \\
\hline & $07 / 13 / 2016$ & & $06: 25$ & 94 & 100 & 0.013 & 0.024 \\
\hline \multirow[t]{2}{*}{ FHWA3511 } & $07 / 12 / 2016$ & Level III & 04:20 & 61 & 71 & 0.016 & 0.044 \\
\hline & $07 / 14 / 2016$ & & 10:01 & 97 & 94 & 0.014 & 0.037 \\
\hline \multirow[t]{2}{*}{ FHWA3512 } & $07 / 13 / 2016$ & Level I & 04:01 & 95 & 96 & 0.016 & 0.025 \\
\hline & $07 / 14 / 2016$ & & $06: 45$ & 97 & 95 & 0.012 & 0.024 \\
\hline Rebar1 & $07 / 12 / 2016$ & $\overline{\text { Level II }}$ & 08:56 & 98 & 99 & 0.01 & 0.028 \\
\hline
\end{tabular}


Single-base RTK GNSS surveys were completed on July 12-14, 2016, using Topcon GR-3 GNSS receivers. The base station was set on a 2-meter fixed height tripod at Rebar1 on July 12, 2016, and at FHWA-3511 on July 13-14, 2016. The single-base RTK GNSS surveys followed techniques and methods for a level II survey as outlined in Rydlund and Densmore (2012). However, owing to the lack of known benchmarks, the unknown quality of the benchmarks used, and the use of single-base static observations to establish survey control, level IV results were the highest single-base RTK GNSS survey level-quality achieved. Observations at TLS scan origins, survey control, back-sight locations, blunder checks, and repeat measurements on observation points were collected at 1 -second intervals for 3 minutes. Seven hundred seventy ground control points also were collected on representative hard and soft surfaces and slopes at various locations throughout the study area for vertical precision verification of the derived DTM. These observation points were collected at 3 -second intervals.

High-resolution topographic data were collected in Grapevine and Tie Canyons within the Scotty's Castle vicinity (fig. 5). A Maptek I-Site 8820 XR TLS, mounted on a standard tripod, was set up at 38 fixed locations with an open field of view to collect 360-degree scans and targeted scans of the topography within the study area. Each scan produces a point cloud of $\mathrm{X}, \mathrm{Y}$, and $\mathrm{Z}$ data referenced to the scan origin. The self-leveling procedure within the Maptek unit was used for every scan. Over 83 million topographic data points were collected during the TLS survey.

The TLS data were processed through an integrated suite of registration, georeferencing, and filtering generally following the framework reported in Collins and others (2014). Each scan contains data for a portion of the study area and must be combined (registered) and spatially located (georeferenced) to a coordinate system. Scan origins (fig. 5) collected from the single-base RTK GNSS survey were input into I-Site Studio software to georeference each scan. Because of an error in the compassing system, individual scans were registered manually using a best fit approach where scans 1, 2, and 3 were rotated about the fixed, georeferenced scan origin, matching overlapping surface features visible in all three scans. The registered and georeferenced group of point clouds were then used as control for an automated alignment of the reaming scans to create a single, point cloud dataset for the entire study area. Ground points were then defined using an iterative, minimum elevation block filtering process.
Overall error position $\left(E_{\text {total }}\right)$ in the TLS data was calculated by treating each component of the survey independently. Potential errors in the TLS data are expected to originate during both data collection and point cloud processing. Error is additive from each component of the TLS data collection: laser error, registration error, georeferencing error, survey error, and control error (Collins and others, 2014). Laser error $\left(E_{\text {laser }}\right)$ can be from either range or angular inaccuracies and is reported by the instrument manufacturer. Registration errors ( $\left.E_{\text {georeference }}\right)$ are a product of combining data from different scan locations into a single coordinate system. Georeferencing errors $\left(E_{\text {georeference }}\right)$ originate from the conversion of the locally registered data into surveyed horizontal projection and vertical datum (for example, North American Datum of 1983 [NAD 83], National Adjustment of 2011 [NA 2011], and North American Vertical Datum of 1988 [NAVD 88] derived from GEOID 12B). Because the registration and georeferencing of the scan data was done through an integrated suite in I-Site, registration and georeferencing error is combined into one component as $E_{\text {georeference. }}$. Surveying errors $\left(E_{\text {survey }}\right)$ originate from the uncertainty in reported $\mathrm{X}, \mathrm{Y}$, and $\mathrm{Z}$ coordinates from comparisons between survey observations and known control locations. Control network errors $\left(E_{\text {control }}\right)$ originate from the known absolute accuracy of the benchmarks used to conduct the GNSS surveys in this study. Control error for this study was estimated as the RMS of peak-to-peak errors of single-baseline static observations as reported by OPUS. Error from each component is additive, producing a conservative, worst case RMS estimate:

$E_{\text {total }}=\sqrt{E_{\text {laser }}^{2}+E_{\text {georeference }}{ }^{2}+E_{\text {lasesurvey }}{ }^{2}+E_{\text {control }^{2}}}$

Error for each component and total error are presented in table 4.

Table 4. Error assessment for maximum errors in terrestrial laser scanning data for Scotty's Castle in Grapevine Canyon, Death Valley National Park, California.

\begin{tabular}{lccccc}
\hline & Laser & Survey & Georeference & Control & Total \\
\hline Horizontal (feet) & 0.02 & 0.10 & 1.56 & 0.29 & 1.56 \\
Vertical (feet) & 0.02 & 0.04 & 0.57 & 0.21 & 0.60 \\
\hline
\end{tabular}




\section{Surface Generation}

To obtain a continuous DTM of the Scotty's Castle study area, the point cloud data must be filtered of extraneous data such as vegetation, fences, power lines, and atmospheric interference (birds, dust, and others), and then a surface is built from the remaining data. Ground points were defined using an iterative process in I-Site Studio that filtered the minimum elevation observations in a defined search area window. Because of the large area scanned and the heavy vegetation, three individual box filters were used to identify ground points (fig. 6). A 5-square-meter ( $\left.\mathrm{m}^{2}\right)$ box filter size was used for areas of heavy vegetation; a $3-\mathrm{m}^{2}$ box filter was used upstream of the Scotty's Castle area, Tie Canyon, and from the confluence of Grapevine and Tie Canyons to the downstream end of the study area; and a $1-\mathrm{m}^{2}$ box filter was used for the immediate Scotty's Castle vicinity. A total of 122,104 points were identified as minimum ground points. The bridge at Scotty's Castle was manually removed from the final surface while the buildings were left as mounds in the final surface. A large amount of flood debris in the main channel near the visitor center and park offices was removed from the DTM because it was a temporary feature that the NPS planned to remove from the channel (Josh Hoines, National Park Service, oral commun., 2017). For this study, the final surface model was created using a triangulated irregular network (TIN) of only the minimum points identified in the filtering process. The extent and spatial distribution of elevations is shown in figure 7.

Vertical accuracy was assessed from the 769 GCPs and reported at the 95th confidence level following the standards for reporting the accuracy of digital geospatial data (American Society for Photogrammetry and Remote Sensing, 2014). Vertical accuracy of the DTM at the 95-confidence level is $2 \mathrm{ft}$, which is within the accuracy guidelines for DTM used in flood inundation mapping for hilly terrain (Federal Emergency Management Agency, 2016). The distribution of GCP residual values are shown in figure 8 . The majority of observed error is on steep slopes, incised channels, and in areas with heavy vegetation. These errors can be explained by the range of elevations associated with steep slopes compared to the interpolated single value of the DTM. Incised channels at distance or in heavy vegetation, such as the area immediately downstream of the bridge, may have been influenced by shadowing. Shadowing occurs when a feature such as a tree on a steep slope blocks a laser return from an area or when thick, low-lying vegetation prevents the laser from reflecting off the ground. The histogram and cumulative percentage plot (fig. 9) show that 81 percent of the DTM error is $0.75 \mathrm{ft}$ and that the DTM has a slightly positive skew. 


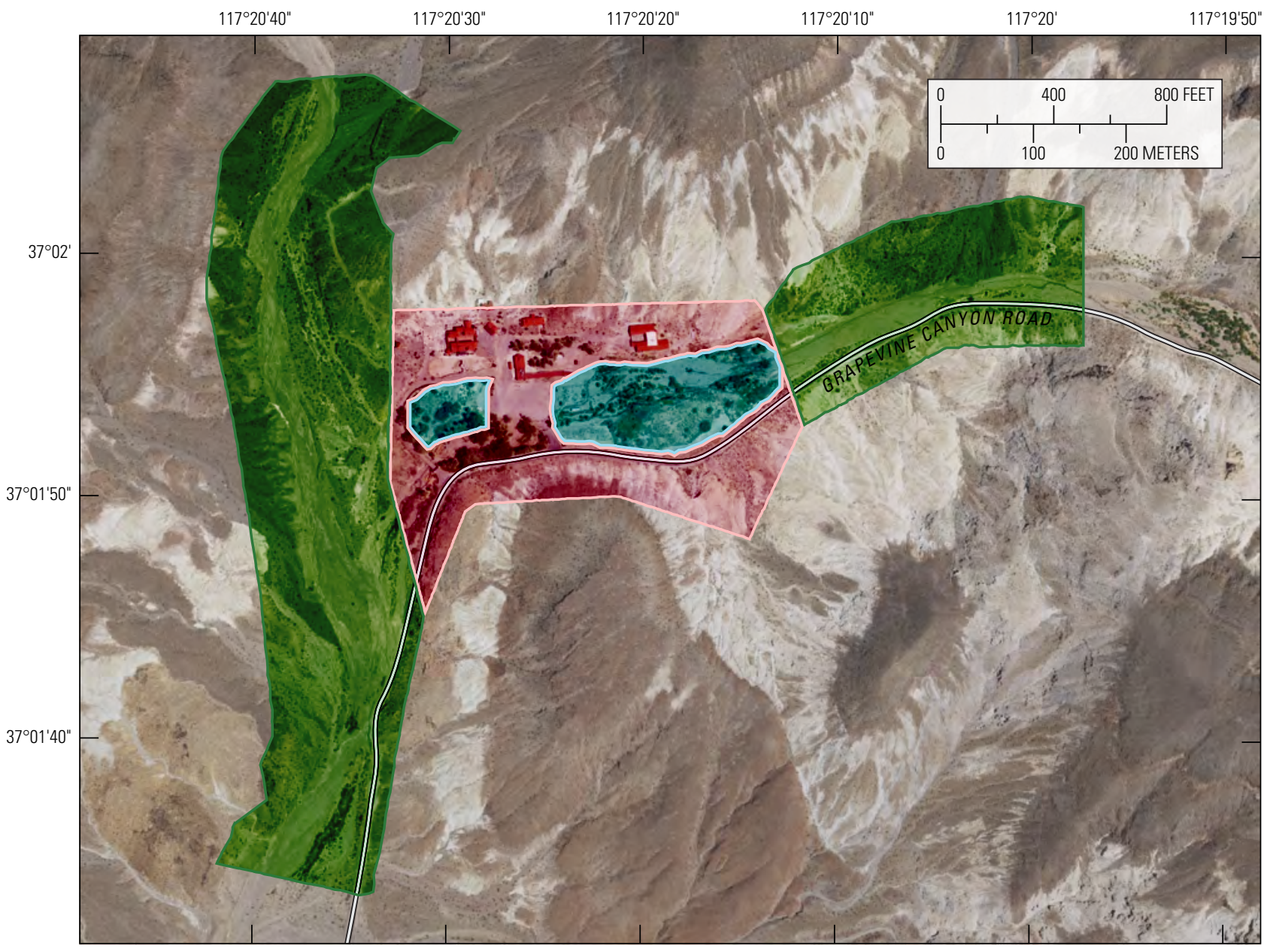

Base modified from National Agricultural Imagery

Program, 2016, 1:8,000 scale. Universal

Transverse Mercator, zone 11,

World Geodetic System of 1984

\section{EXPLANATION}

5-square-meter filter area

3-square-meter filter area

1-square-meter filter area

Figure 6. Terrestrial laser scanner minimum elevation filtering areas used to create the digital terrain model for Scotty's Castle in Grapevine Canyon, Death Valley National Park, California. 


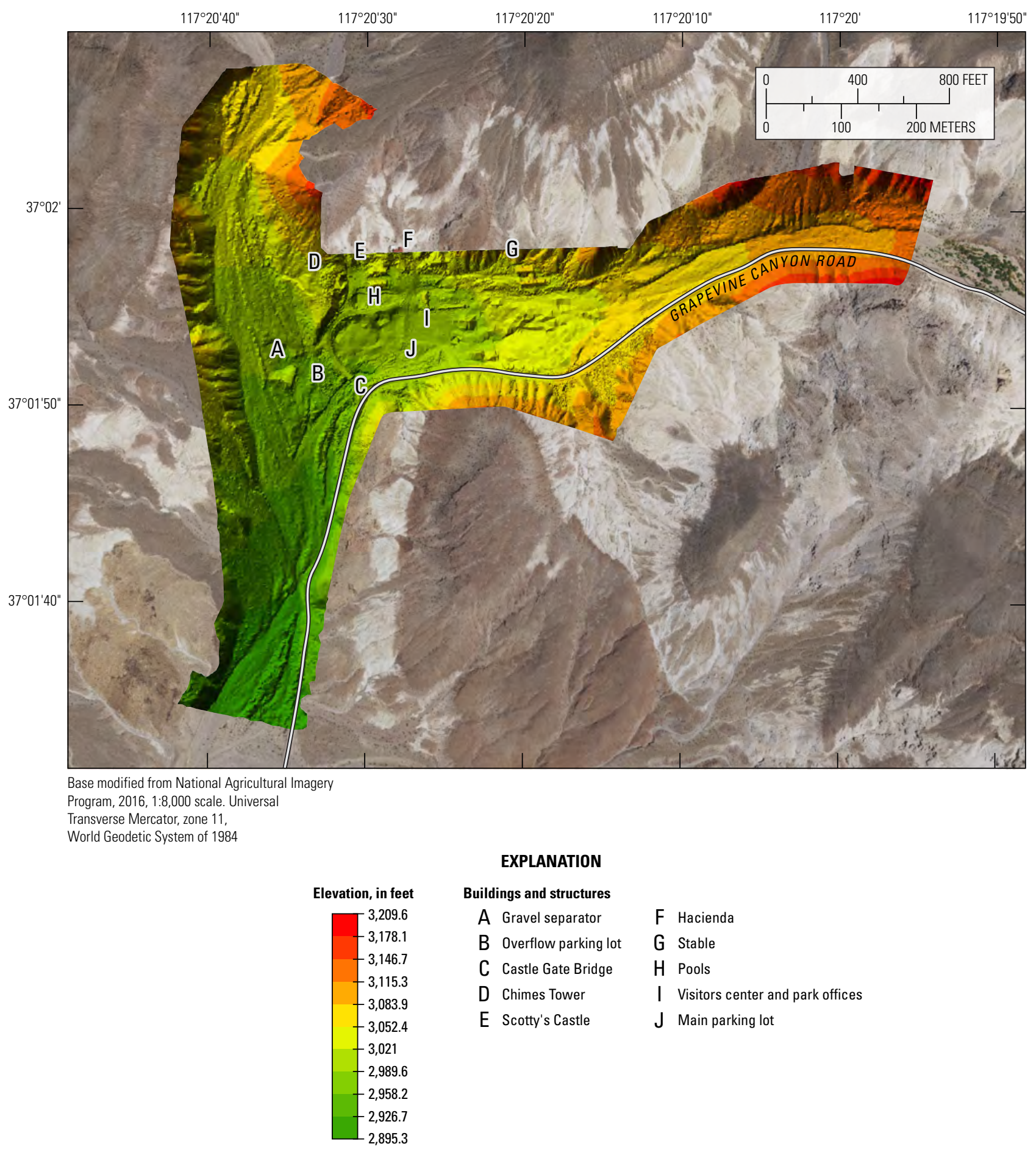

Figure 7. Digital terrain model for Scotty's Castle in Grapevine Canyon, Death Valley National Park, California. 


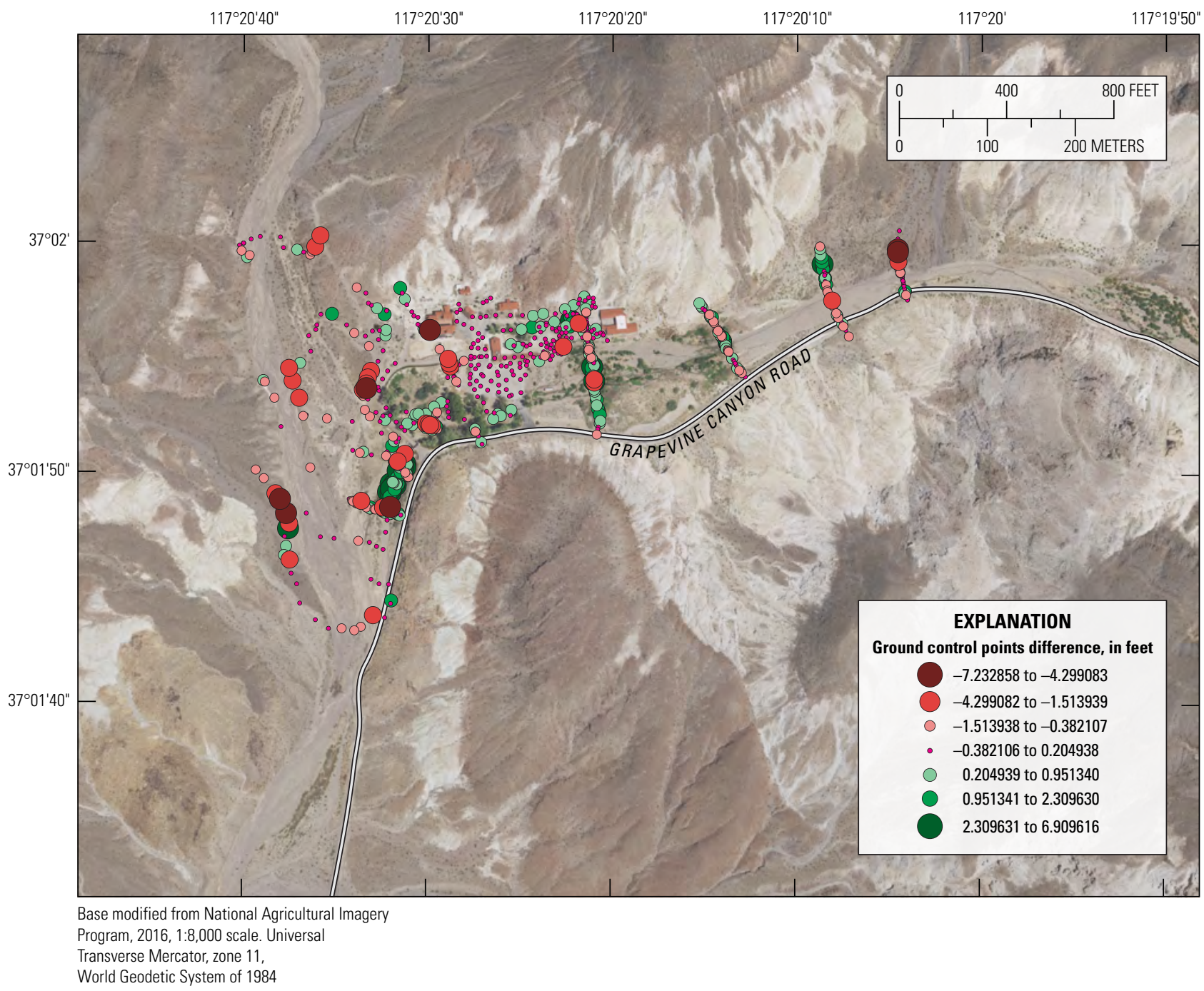

Figure 8. Spatial distribution of measured residual error between ground control points and the digital terrain model for Scotty's Castle in Grapevine Canyon, Death Valley National Park, California. 


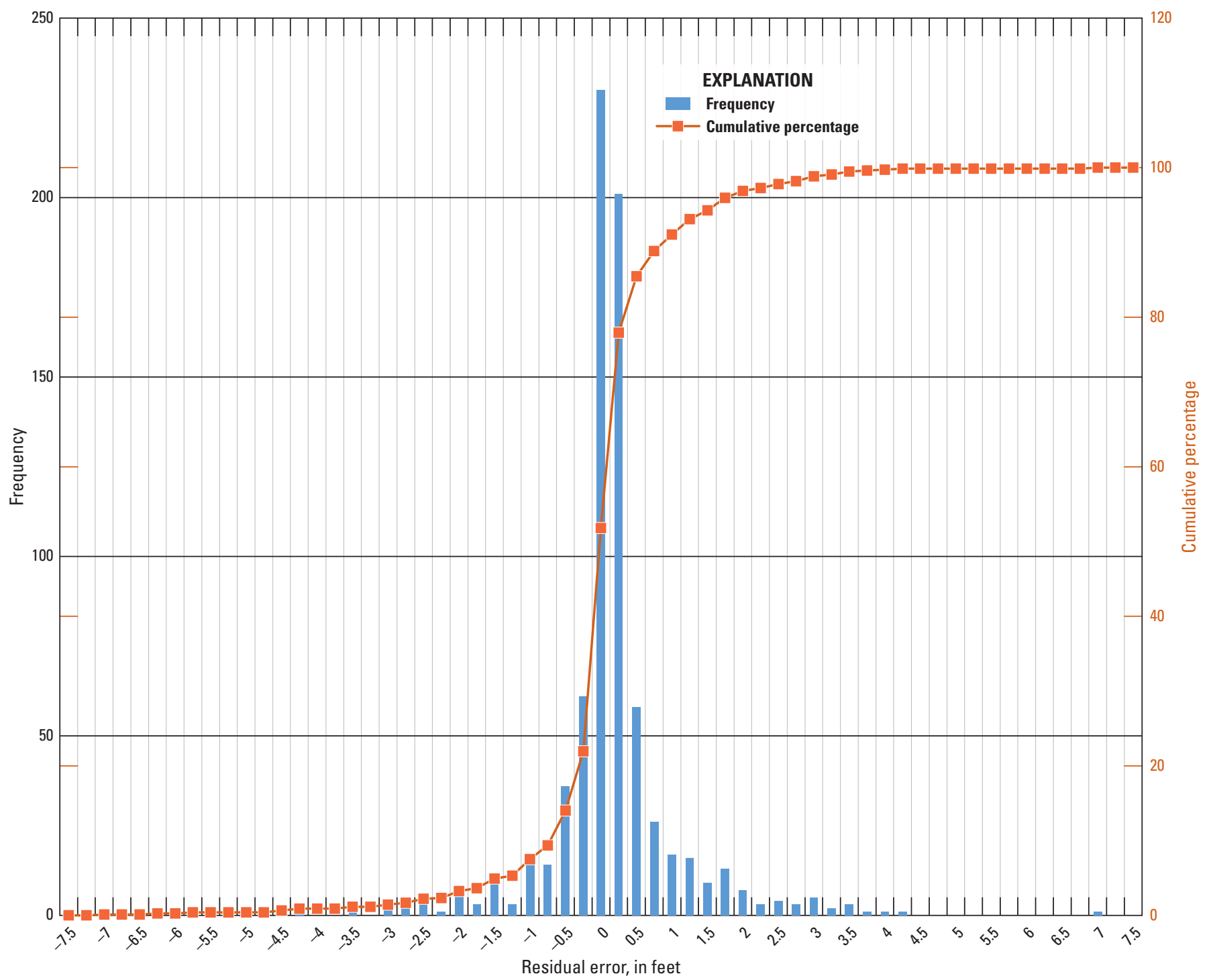

Figure 9. Histogram and cumulative percentage of residual error between ground control points and the digital terrain model for Scotty's Castle in Grapevine Canyon, Death Valley National Park, California.

\section{Hydraulic Modeling}

The hydraulic modeling was done with the U.S. Army Corps of Engineers Hydrologic Engineering Center-River Analysis System (HEC-RAS), version 5.0.7 (U.S. Army Corps of Engineers, 2019). A one-dimensional step-backwater model, HEC-RAS computes open-channel streamflow using channel geometry and channel roughness. The streamflows of the computed AEP floods were used to determine water surface elevations for each cross section. With no hydrograph or water surface elevations for the varying streamflows to use for boundary conditions, the normal slope $\left(S_{n}\right)$ was set equal to the channel slope $\left(S_{o}\right)$, defining the boundary conditions for
Grapevine Canyon downstream end $\left(S_{n}=0.04\right)$. Due to the very steep channel, supercritical streamflow could be computed by the model; however, the ability of supercritical streamflow to occur over long distances in alluvial channels has been questioned (Grant, 1997). Rather, as streamflow increases, turbulence and the formation of bed forms cause an increase of roughness and subcritical or critical flow to occur (Jarrett, 1984; Costa and Jarrett, 2008). Since supercritical flow would result in a lower water surface to be computed, a conservative approach was used and the model was run in subcritical model, allowing only subcritical and critical streamflow. Expansion and contraction coefficients were set at 0.5 and 0.0, respectively (Davidian, 1984). 


\section{Model Geometry}

The U.S. Army Corps of Engineers Hydrologic Engineering Center Geo River Analysis System (HEC-GeoRAS) ArcMap extension, version 10.3, was used to extract cross sections and delineate buildings from the TLS-derived DTM to define the model geometry (U.S. Army Corps of Engineers, 2015). A total of 539 cross sections were extracted for six defined model reaches and used for model simulations. Modifications were made to the bridge because the TLS scans did not adequately define the bridge structure. The modifications were based on manual width, length, and depth measurements.

Six separate model stream reaches were defined for the model to describe the six primary streamflow channels (fig. 2). Upper Grapevine Canyon was defined from the upstream end of the surveyed area to approximately $300 \mathrm{ft}$ downstream of the bridge. Middle Grapevine Canyon was defined from approximately $300 \mathrm{ft}$ downstream of the bridge to the main confluence with Tie Canyon. Lower Grapevine Canyon was defined from this confluence to the downstream end of the surveyed area. Upper Tie Canyon was defined from the upstream end of the surveyed area to just upstream of the gravel separator (a large historical structure used during the construction of Scotty's Castle). Lower Tie Canyon was defined from upstream of the gravel separator to the main confluence with Grapevine Canyon. Side Channel was defined as the distributary channel from upstream of the gravel separator to approximately $300 \mathrm{ft}$ downstream of the bridge.

Near the Tie and Grapevine Canyon confluence, Lower Tie Canyon, Side Channel, Middle Tie Canyon, and the lower portion of Upper Tie Canyon all become one continuous area of inundation at higher streamflows. The boundaries of these channels were arbitrarily set at higher locations between defined channels when possible, with the model assuming a vertical bank at this point. This was done to reduce errors associated with large changes in water surface between cross sections.

Several of the buildings at Scotty's Castle were defined as obstructions. It is possible the largest streamflows could damage the buildings to such an extent to allow some conveyance of streamflow; however, the conveyance would be minimal compared to the entire channel. Ineffective streamflow areas, or areas where water would pool but not convey streamflow, were defined near the bridge and in backwater areas.

\section{Model Hydrology}

Because of the multiple confluences, AEP flows were assigned to each model reach in three different ways. The regional regression equations and the drainage areas were used to determine the streamflow for Upper Grapevine and Upper Tie Canyons. Lower Grapevine Canyon was determined by an addition of Upper Grapevine and Upper Tie Canyons streamflows. Middle Grapevine Canyon was determined by an addition of Upper Grapevine and Side Channel flows. Because Lower Tie Canyon and Side Canyon are distributaries (rather than tributaries) of Upper Tie Canyon, simple addition of streamflow could not be done. Instead, the "flow optimization tool" in HEC-RAS was run using the inflow from Upper Tie Canyon and varying the streamflow going down both Lower Tie Canyon and Side Channel until a balance of water surface and energy grade lines was reached.

\section{Roughness Coefficients}

The streamflow of a channel is controlled not just by the geometry (cross sections and slope) but also by friction with the channel bed and vegetation growing in the channel. Channel roughness, as defined by Manning's $n$-value, was estimated for cross sections using tables for channel material (base $n$-value) and adjusting for channel irregularities, obstructions, and vegetation to determine a final $n$-value (Chow, 1959; Arcement and Schnieder, 1989). Where overbank areas occurred, additional $n$-values were estimated using the same process. Estimated $n$-values were also compared with photographs of streams with determined roughness values to verify the final values (Barnes, 1967; Aldridge and Garrett, 1973; Phillips and Ingersoll, 1998). The final selected $n$-values ranged from 0.017 to 0.13 . The higher values in the specified ranges were used for areas just upstream of Scotty's Castle and downstream of the bridge for dense riparian vegetation growing in the channel as well as overbank locations in Upper Tie Canyon where piles of railroad ties act as additional obstructions. The lower values were for the pavement of either the parking lot or the Grapevine Canyon Road.

As an additional check on roughness, the measured channel bed particle size was used to compute a base $n$-value (without adjustments) based on work done in California by Limerinos (1970) ${ }^{1}$ and a geographically diverse dataset by Rickenmann and Recking (2011):

$$
n_{b}=\frac{0.113 R^{1 / 6}}{1.16+2.0 \log \frac{R}{d_{84}}}
$$

$$
n_{b}=\frac{d_{84}^{0.167}}{20.4}
$$

where $n_{b}$ is the base $n$-value, $R$ is the hydraulic radius in meters, and $d_{84}$ is the particle size that exceeds that of 84 percent of the particles in meters. The 1-AEP streamflow was used to compute the hydraulic radius.

\footnotetext{
1This is a metric form of the equation as given in Bray and Davar (1987).
} 


\section{Model Calibration}

Because no gaging stations had been operation in the area before December 2016, model calibration data was limited to the indirect measurement surveyed for the October 18 , 2015, flood (at the upstream end of the Upper Grapevine Canyon model reach). The model was run using the indirect streamflow of 3,200 cfs in Grapevine Canyon. The modeled water surface was compared with the surveyed high-water marks (quality good to poor) from the indirect measurement surfaces (fig. 10). When the indirect measurement was computed, it was found that there was a very large decrease in cross-sectional area and increase in velocity in the middle of the reach in contrast to all other parts of the surveyed indirect reach. The significant difference of channel hydraulic properties along with photographic examination of the channel and weather radar data of the movement of the thunderstorm provided ample evidence that an unnamed side canyon had deposited fill in the middle of the indirect measurement reach after the main flood peak in Grapevine Canyon. Therefore, the high-water marks from the main flood peak would not represent the water surface for the same streamflow in the current channel because fill happened after the peak. Additionally, after the indirect measurement survey, but before the TLS survey, gravel and cobble fill from the road had been moved and placed within the main channel, further complicating the comparison. When impacted high-water marks associated with cross sections that were affected by the greatest fill were removed from consideration, the mean model water surface was found to be on average $0.22 \mathrm{ft}$. higher than the high-water marks. This is within the accuracy of the surveyed high-water marks $(0.20-0.40 \mathrm{ft})$ from the indirect measurement survey. Because the reach was already computing as critical flow, lowering the n-value would not decrease the water surface further. For these reasons, no additional modifications to the model were made.

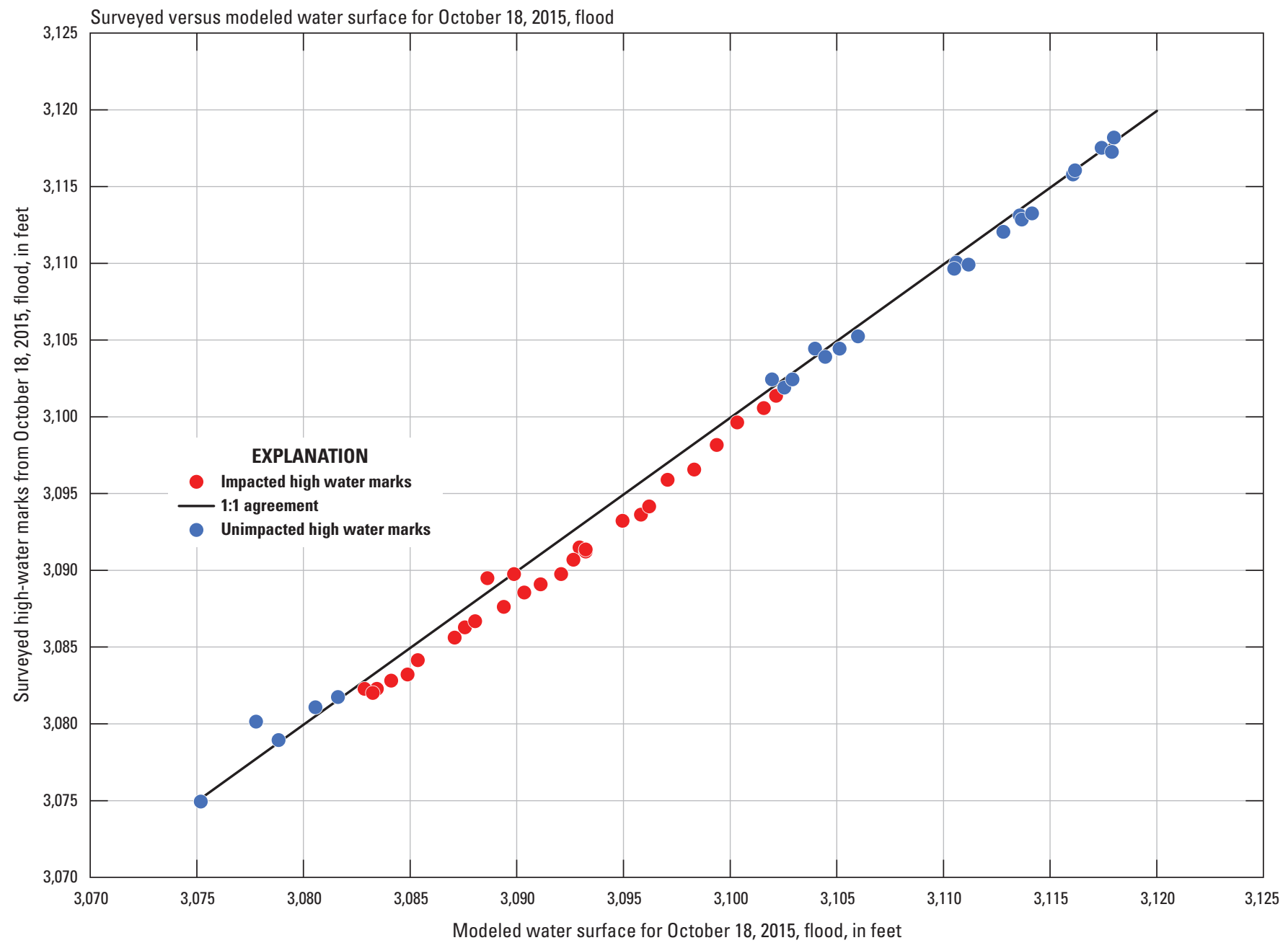

Figure 10. Surveyed versus modeled water surface for October 18, 2015, flood at Scotty's Castle in Grapevine Canyon, Death Valley National Park, California. 
Elsewhere in Grapevine Canyon and Tie Canyons, removal of the high-water marks from the October 18, 2015, flood by weather and maintenance crews was done before the TLS surveys were completed; therefore, additional calibration points could not be determined for that flood.

After the creation and the execution of the HEC-RAS model, the resulting inundation areas were imported into a geographic information system. Near the confluence of Tie and Grapevine Canyons, streamflow became two-dimensional and was not adequately mapped using the one-dimensional model. Examples include additional braided channels in lower Tie Canyon and lower Grapevine Canyons (where streamflow would continue downstream, not stopping at a cross section), the arbitrary boundaries between channels as described above, and the overflow of the bridge and embankment in upper Grapevine Canyons (where the model computed streamflow was confined to the channel downstream of the bridge despite streamflow occurring over the top of the embankment). Areas were manually added to the inundation layers in locations where streamflow was inferred to occur; these manually added areas were marked as "inferred inundation area" to indicate additional uncertainty.

\section{Sensitivity Analysis}

In addition to the final computation as described (named final scenario), two other computations were run for every AEP to provide some indication of uncertainty. A high-water surface scenario was created, assuming vegetation grows back to the moderately to extremely dense vegetation that existed in the active channel of Grapevine Canyon before the October 18, 2015, flood. Imagery and photographs before the flood indicated very dense willow and mesquite extending from the Grapevine Canyon-Tie Canyon confluence to the upstream side of the bridge and from upstream side of the parking lot to $850 \mathrm{ft}$ upstream. Downstream of the Grapevine Canyon-Tie Canyon confluence and distances greater than $850 \mathrm{ft}$ above the parking lot, moderately dense vegetation was present in the active channel. The $n$-values for these areas were mostly raised from 0.045 to 0.12 . In Tie Canyon, the $n$-value was raised slightly for somewhat denser vegetation that was growing in the active channel before the flood.

In addition to the higher $n$-value for vegetation, on both the upstream and downstream side of the bridge, the large channel incision that took place during the flood was filled in to return the area to the pre-flood state. Because no recent survey data exist to determine the exact height of the land surface near the bridge before the flood, a flat surface with the surrounding land was used. This resulted in channels approximately $1-10.5 \mathrm{ft}$ shallower than in the final scenario near the bridge.

A low-water-surface scenario was also created, assuming the channel was maintained to be clear of thick vegetation downstream of the bridge and upstream of the parking lot. The channel incision near the bridge was also kept in its current state. In Lower Grapevine Canyon and Tie Canyon, the low-water-surface scenario assumed some minor reduction in vegetation resulting in slightly lower roughness. These additional computations are plotted on the same maps as the final scenario computation.

\section{Results}

The flood-inundation maps are presented in figures 11-15. The park offices, visitor center, parts of Grapevine Canyon Road, and the bridge are inundated by the 2-AEP flood; however, none of the computed flows reach Scotty's Castle proper, the Chimes Tower, or the Hacienda. The model computes steep, fast, critical streamflow for most of the study reaches for all the computed AEP flood streamflows. However, upstream of the bridge and in areas with dense vegetation, high roughness coefficients reduce velocities and cause subcritical streamflow to be computed.

\section{Grapevine Canyon}

All the AEP flood streamflows modeled inundate Grapevine Canyon Road near the upper end and lower end of the surveyed reach where the channel is nearly the same elevation as the road. Streamflow starts to reach the southeast corner of the visitor center and park offices at the 4-AEP flood (fig. 11). The 2-AEP (fig. 12), 1-AEP (fig. 13), and 0.5-AEP floods (fig. 14) have more streamflow directed around the north side of the visitor center and park offices where the ground is sloped toward the building itself. By the 0.2-AEP flood, streamflow has nearly surrounded the building (fig. 15). The stable also has a similar hazard on the east side. However, streamflow does not reach the stable until the 0.5-AEP flood.

The 4-AEP flood computed streamflow was confined to the bridge and pooling behind the embankment. At the 2-AEP flood, the bridge and embankment are overtopped, and by the 0.2 -AEP flood, the overtopping streamflow is nearly $6 \mathrm{ft}$ in depth.

Downstream of the embankment, the overflow parking lot terrace would be partially affected by all the AEP floods owing to streamflow from the north and northwest occurring through Side Channel. Without well-defined channels, streamflow could either spread out or incise and cut new channels. By the 2-AEP flood, where the embankment is overtopped, there would be additional streamflow on this terrace coming from Upper Grapevine Canyon, resulting in streamflow coming at very different angles.

The sensitivity analysis illustrates the effects that different management scenarios would have on the water levels. The 4-AEP flood high-water scenario has streamflow reaching the visitor center and park offices as well as overtopping the bridge and embankment, whereas this does not occur in the final and low water scenario until the 2-AEP flood. 


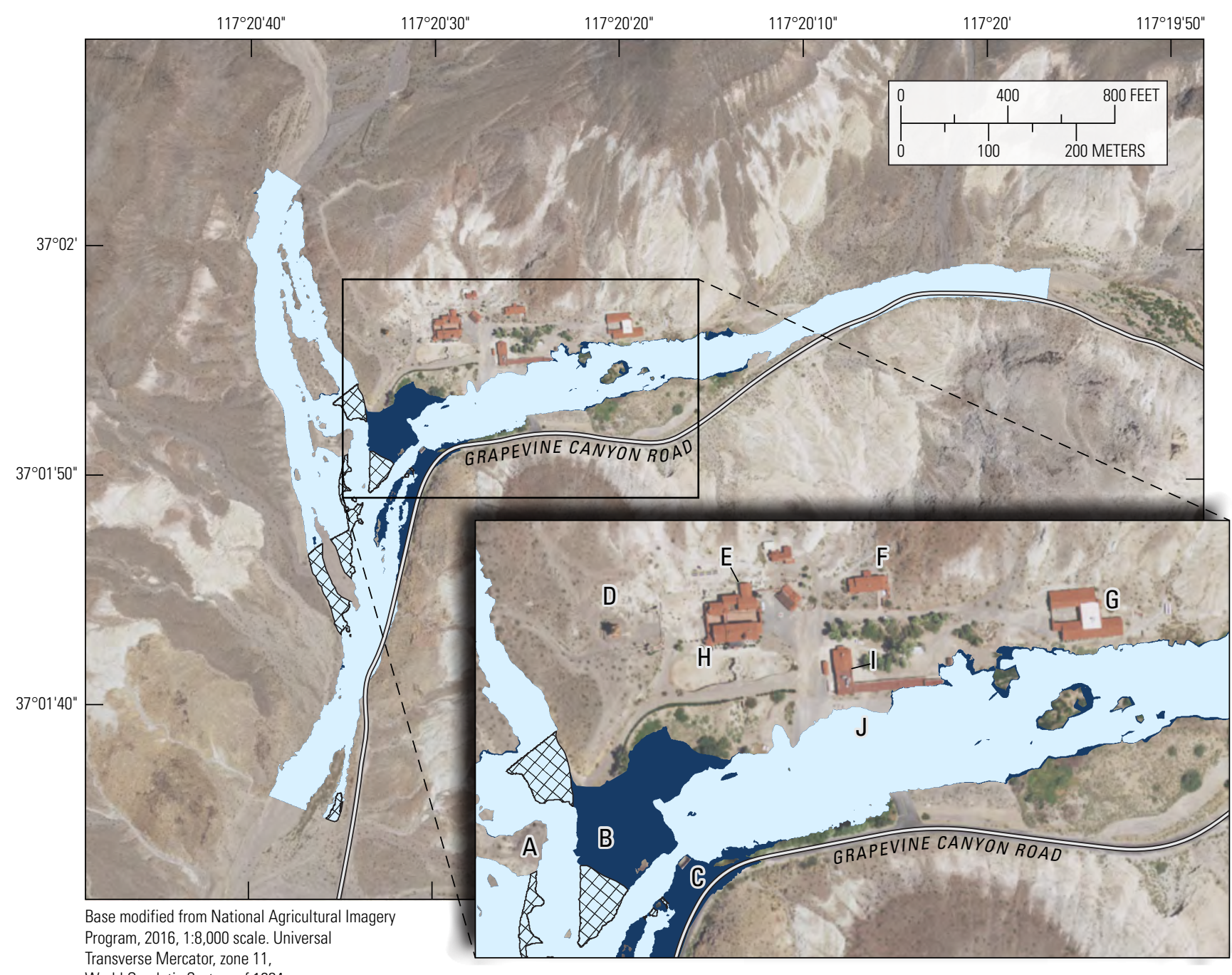

Transverse Mercator, zone 11,

\section{EXPLANATION}

4-percent annual exceedance probablity (AEP) streamflow

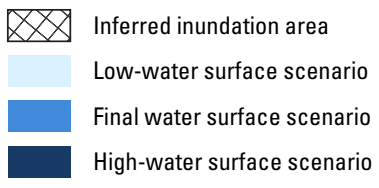

\section{Buildings and structures}
A Gravel separator
F Hacienda
B Overflow parking lot
G Stable
C Castle Gate Bridge
$\mathrm{H}$ Pools
D Chimes Tower
I Visitors center and park offices
E Scotty's Castle

Figure 11. Flood-inundation areas for the 4-percent annual exceedance probability flood streamflow for Scotty's Castle in Grapevine Canyon, Death Valley National Park, California.

\section{Tie Canyon}

All the AEP floods result in streamflow leaving the active channel located on the west side of the canyon and flowing onto the higher Upper Tie Canyon terrace on the east side. The 4-AEP flood (fig. 11) results in braided streamflow on this terrace. The terrace becomes completely inundated at flows greater than or equal to the 0.2-AEP flood streamflow (fig. 15). All the computed AEPs have streamflow leaving the main channel near the upstream end of Tie Canyon and following an old road that goes along the base of the hill to the overflow parking lot downstream of the bridge. Further downstream, approximately 45-54 percent of streamflow is directed southeast down the Side Channel created during the October 18, 2015, flood, with the percentage increasing with larger streamflow.

The sensitivity analyses in Tie Canyon show that the inundated extent is limited by the steep side slopes of the canyon, and the different computations result mostly in changes to the inundation depth. 


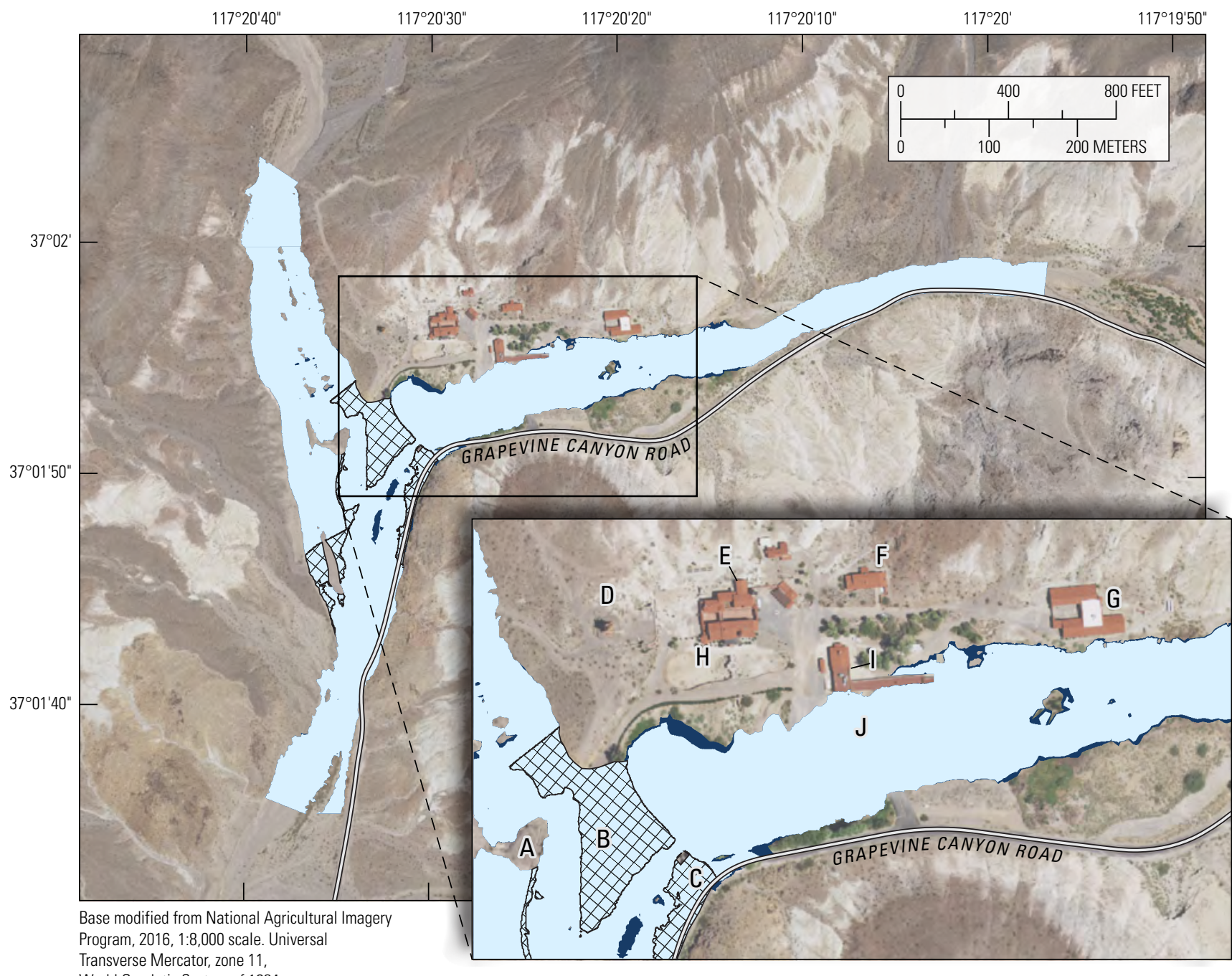

Transverse Mercator, zone 11,

\section{EXPLANATION}

2-percent annual exceedance probablity (AEP) streamflow

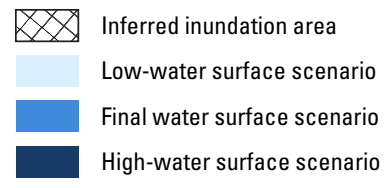

\section{Buildings and structures}
A Gravel separator
F Hacienda
B Overflow parking lot
G Stable
C Castle Gate Bridge
$\mathrm{H}$ Pools
D Chimes Tower
I Visitors center and park offices
E Scotty's Castle

Figure 12. Flood-inundation areas for the 2-percent annual exceedance probability flood streamflow for Scotty's Castle in Grapevine Canyon, Death Valley National Park, California. 


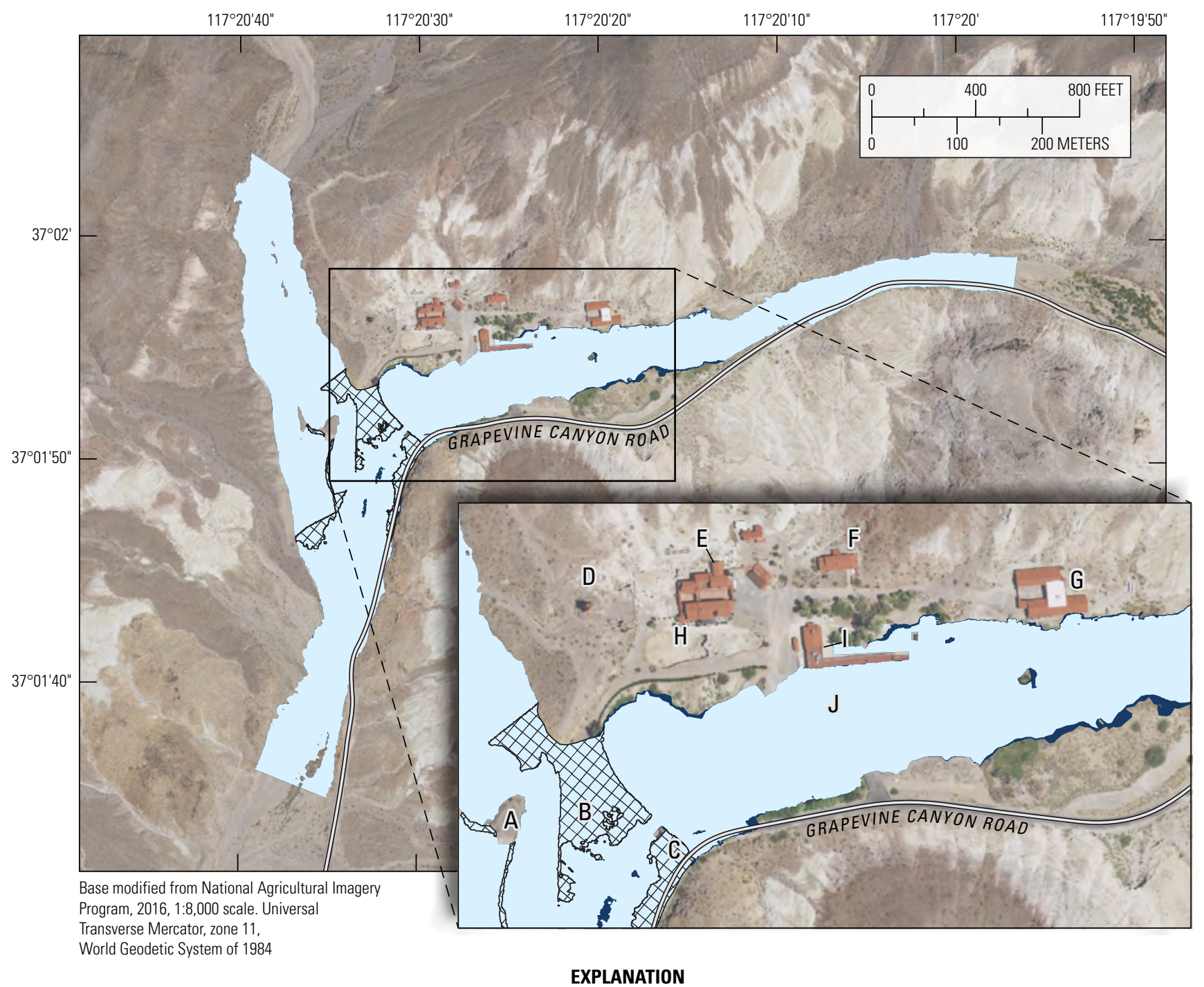

1-percent annual exceedance probablity (AEP) streamflow

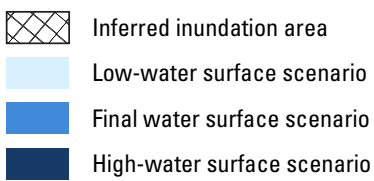

Buildings and structures
A Gravel separator
F Hacienda
B Overflow parking lot
G Stable
C Castle Gate Bridge
H Pools
D Chimes Tower
I Visitors center and park offices
E Scotty's Castle
$J$ Main parking lot

Figure 13. Flood-inundation areas for the 1-percent annual exceedance probability flood streamflow for Scotty's Castle in Grapevine Canyon, Death Valley National Park, California. 


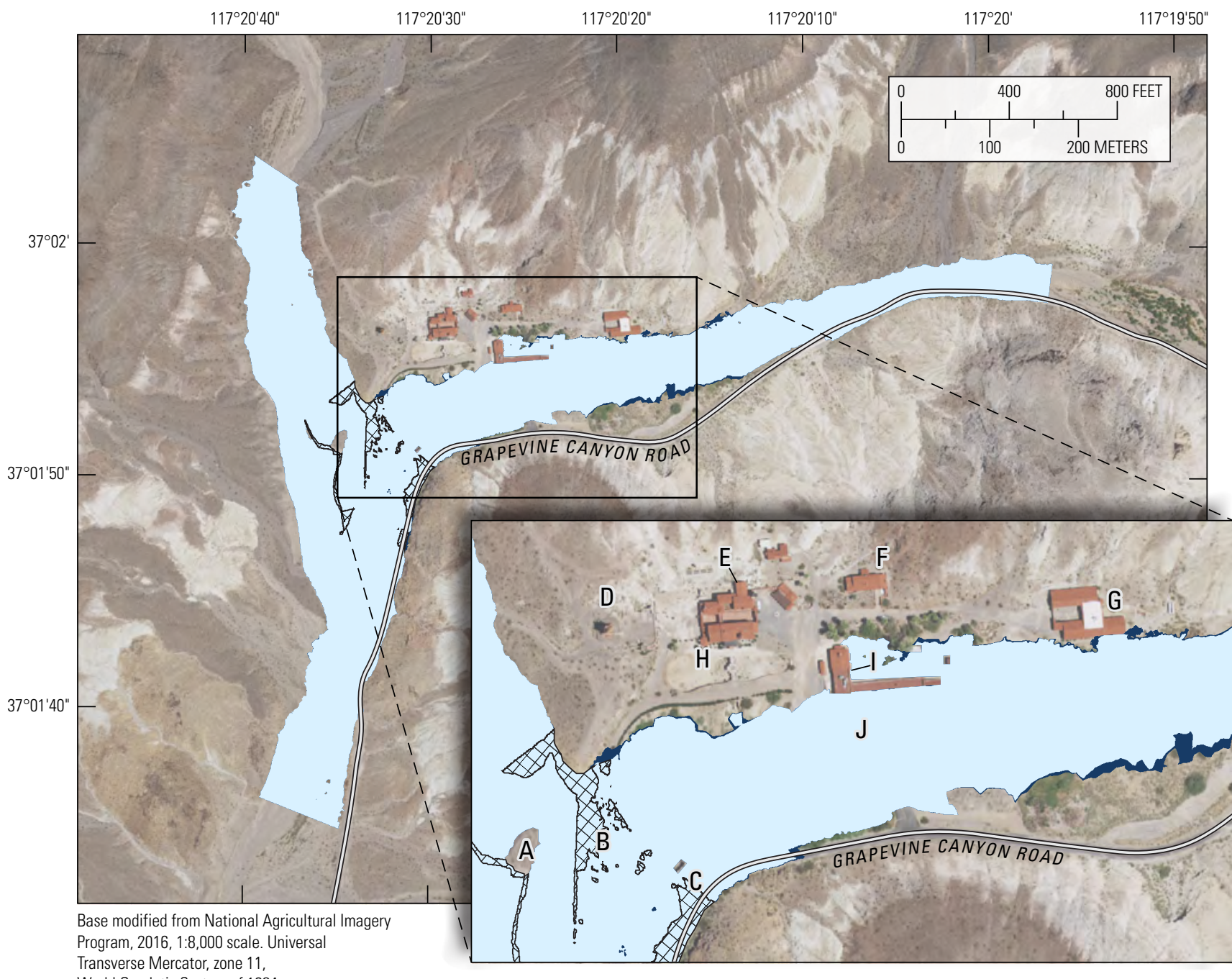

Transverse Mercator, zone 11,

\section{EXPLANATION}

0.5-percent annual exceedance probablity (AEP) streamflow

Inferred inundation area
Low-water surface scenario
Final water surface scenario
High-water surface scenario
Buildings and structures
A Gravel separator F Hacienda
B Overflow parking lot $G$ Stable
C Castle Gate Bridge H Pools
D Chimes Tower I Visitors center and park offices
E Scotty's Castle J Main parking lot

Figure 14. Flood-inundation areas for the 0.5-percent annual exceedance probability flood streamflow for Scotty's Castle in Grapevine Canyon, Death Valley National Park, California. 


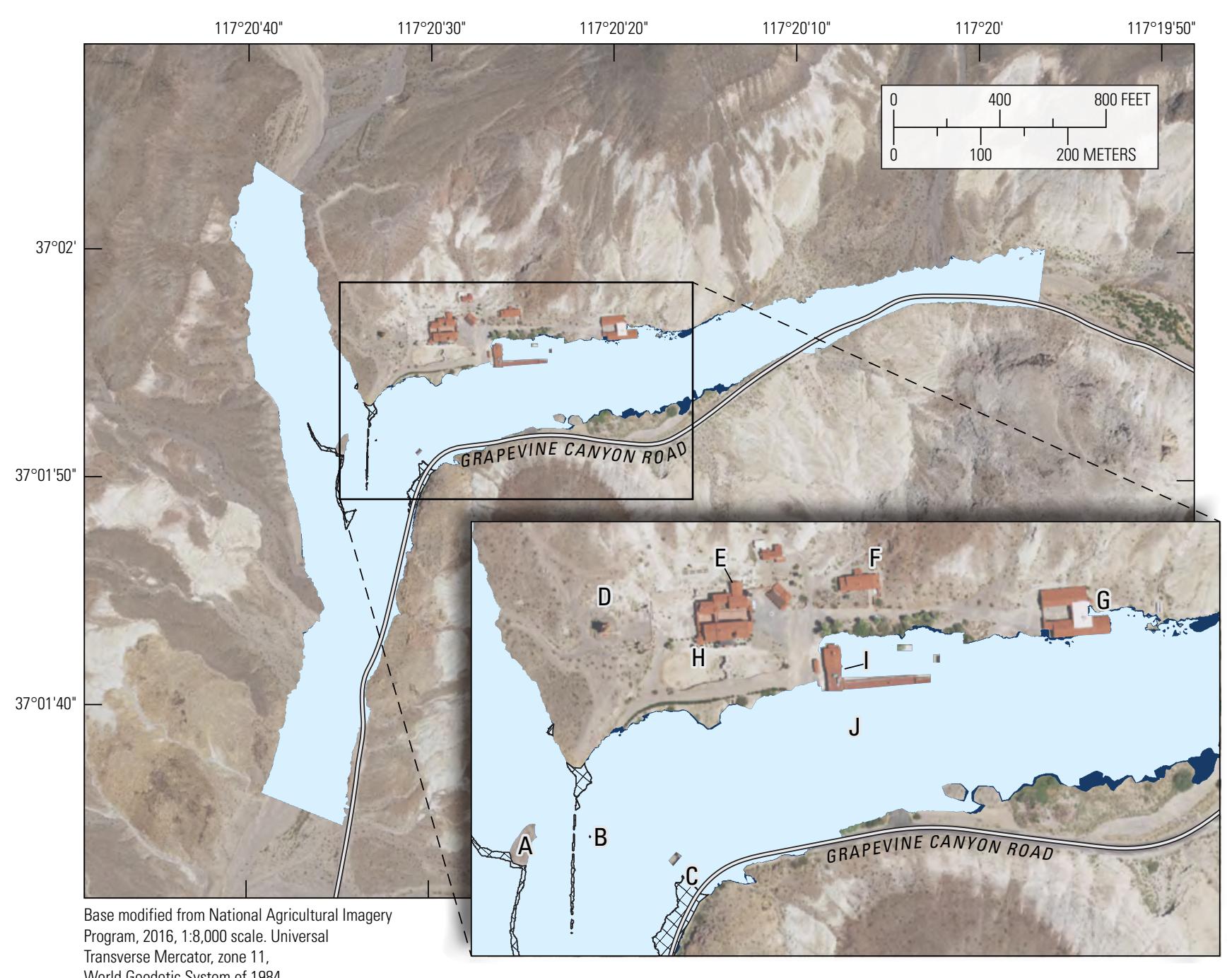

EXPLANATION

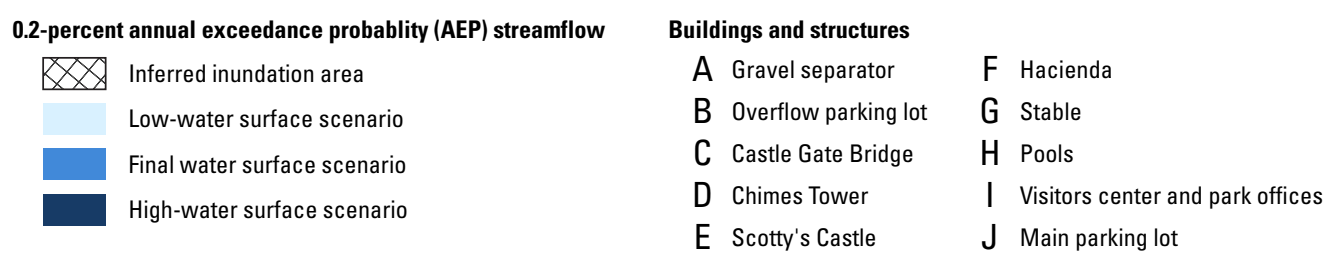

Figure 15. Flood-inundation areas for the 0.2-percent annual exceedance probability flood streamflow for Scotty's Castle in Grapevine Canyon, Death Valley National Park, California.

\section{Channel Bed Particle Size and Roughness}

The result of the pebble counts to determine the channel bed particle size are presented in table 5. Median grain size $\left(d_{50}\right)$ ranged from 8 to 16 millimeters $(\mathrm{mm})$, or medium gravel. The $d_{84}$, or the particle size that exceeds that of 84 percent of the particles, ranged from 32 to $180 \mathrm{~mm}$, or very coarse gravel to cobble. The computed base $n$-values from equations by Limerinos (1970) and Rickenmann and Recking (2011) are within the range of $n$-values given for gravel by Arcement and Schnieder (1989) apart from Tie Canyon Overbank, which had a larger percentage of boulders. 
Table 5. Results of pebble counts and computed $n$-values for Scotty's Castle in Grapevine and Tie Canyons, Death Valley National Park, California.

$\left[d_{50}\right.$, particle size exceeds that of 50 percent of the particles; $d_{84}$, particle size exceeds that of 84 percent of the particles; $\mathrm{mm}$, millimeter]

\begin{tabular}{lcrccc}
\hline \multicolumn{1}{c}{ Location } & $\begin{array}{c}\boldsymbol{d}_{\mathbf{5 0}} \\
(\mathbf{m m})\end{array}$ & $\begin{array}{c}\boldsymbol{d}_{\mathbf{8 4}} \\
(\mathbf{m m})\end{array}$ & $\begin{array}{c}\text { Base } \boldsymbol{n} \text { - } \\
\text { value }\end{array}$ & $\begin{array}{c}\text { Computed base Computed base } \\
\text { n-value }\end{array}$ & $\begin{array}{c}\text { n-value } \\
\text { n-van }\end{array}$ \\
\hline Grapevine Overbank & 8 & 64 & $0.028-0.035$ & 0.035 & 0.031 \\
Grapevine Main & 16 & 64 & $0.028-0.035$ & 0.031 & 0.031 \\
Tie Overbank & 16 & 180 & $0.028-0.035$ & 0.047 & 0.037 \\
Tie Main & 16 & 45 & $0.028-0.035$ & 0.030 & 0.029 \\
Confluence & 11 & 32 & $0.028-0.035$ & 0.027 & 0.028 \\
\hline
\end{tabular}

1From Limerinos (1970).

${ }^{2}$ From Rickenmann and Recking (2011).

\section{Discussion}

The model indicates several buildings, roads, and the bridge remain susceptible to flooding. The largest hazards include the overtopping of the bridge and how side channel will respond to future floods.

\section{Grapevine Canyon}

None of the computed flows reach Scotty's Castle main building. However, the area around Scotty's Castle is still subject to gully and overland flow from the nearby hillslopes as occurred during the October 18, 2015, flood, which deposited sediment and debris in this area.

The greatest hazard is at the bridge and embankment. In all three streamflow scenarios, the bridge and embankment are overtopped. The 0.2-AEP flood has a depth of nearly $6 \mathrm{ft}$ over the bridge and embankment. Because of the approximately $6 \mathrm{ft}$ drop in the water surface from the upstream to the downstream sides of the bridge, significant amounts of erosion would be possible on the downstream side of the embankment. If a failure of the embankment were to occur ${ }^{2}$, it would cause a drastic drop in the water surface upstream, with a large release of the water, sediment, and entrained debris.

At the overflow parking lot terrace, because of the lack of defined channels, streamflow could either spread out or incise and cut new channels. Given the steep slope and large difference in elevation from the overflow parking lot terrace to the main channel, an incision working backwards into the terrace is possible. At AEP floods in which the embankment

\footnotetext{
${ }^{2} \mathrm{~A}$ technical structure survey would be needed to determine the actual risk of embankment failure and is beyond the scope of this report.
}

is overtopped, there would be additional streamflow on this terrace coming from Upper Grapevine Canyon, resulting in streamflow coming at very different angles. In such an event, very complex interactions of the streamflow and the incision would occur and probably vary significantly over the course of the flood.

The visitor center, park offices, and stable all face unique hazards because the adjacent ground terrain slopes downhill into the buildings. The slope direction has the potential to be more hazardous and damaging as streamflow, sediment, and entrained debris are directed into the buildings, which occurred during the October 18, 2015, flood.

\section{Tie Canyon}

In Tie Canyon, the largest uncertainty is how Side Channel may respond to future streamflows. Side Channel appeared to have been created by streamflow following an old road during the 2015 flood. Lower Tie Canyon functions as an alluvial fan, and it is very common for streamflow to switch distributary channels or rapidly create new channels during floods on fans (National Research Council, 1996). Therefore, depending on the variable channel conditions on this fan, it is possible for Side Channel to convey significant but variable streamflows that could even become the primary channel for Tie Canyon, directing the streamflow onto the overflow parking lot terrace. This scenario could cause additional damage to the overflow parking lot, potentially resulting in additional fill being deposited near the exit of the bridge, and cause backwater conditions resulting in higher water surface elevations upstream of the bridge. Additionally, increased streamflow in Side Channel would cause higher velocities very close to the gravel separator that could lead to damage of the historic structure. 


\section{Uncertainties and Limitations}

The hydraulic model and maps produced in this study have uncertainties and limitations that are detailed below. Uncertainties are cumulative and include limited understanding of the hydraulics of very steep, erodible-bed channels; the possibility of significant channel changes from both floods and management; the limits of one-dimension modeling; and the reliance on regional regression equations. The mapped inundation areas should not be viewed as absolute, but rather a prediction within a larger ensemble of possibilities.

\section{Physical Limitations}

Most significantly, the model is a snapshot of the conditions during the topographic data collection survey. The sensitivity analysis provides general guidance on how different management strategies could affect the flood-inundation areas; it does not cover every possible scenario. Changes to the channel or bridge geometry would affect the computed water surface elevations. For example, the construction of berms to protect an area against flooding would likely cause higher water surface elevations for a given streamflow for the remainder of the channel near the berms. Conversely, channel enlargement would cause lower water surface elevations.

The channel is subject to unknown scour and fill during flood streamflows. Scour at the peak would cause a larger cross-sectional area, and therefore lower water surface elevations, for a given streamflow, whereas fill at the peak would cause higher water surface elevations for a given streamflow. Additionally, such scour and fill would vary spatially and temporally with bed armoring, channel form, wave form, and streamflow (Hooke and Mant, 2000; Powell and others, 2007).

The actual channel roughness may vary from those used; a higher roughness would cause higher water-surface elevations for a given streamflow, whereas a lower roughness would cause lower water surface elevations for a given streamflow. Roughness is variable in time with seasonal changes to vegetation and the movement of sediment during floods (Bray and Davar, 1987). Finally, nearly all information about $n$-values are from lower gradient channels, which has been found to underestimate $n$-values for high gradient channels (Jarrett, 1984; Marcus and others, 1992).

Floods can carry substantial amounts of debris that can get lodged on trees, boulders, or other features. Such flood debris can direct streamflow in varying directions, causing higher velocities and erosion in places than would otherwise occur. Flood debris can also block streamflow and would be most impactful at the bridge and immediately upstream from the bridge, where debris would reduce conveyance and cause higher water surface elevations.

\section{Model Limitations}

Although most of the channel was suitable for one-dimensional modeling using the step-backwater method, the area near the confluence of Tie and Grapevine Canyons was not. Because of the various angles of streamflow (both from Side Channel and over the top of the bridge embankment in Grapevine Canyon), braided channels, arbitrary boundaries between channels that have a single inundation surface at higher streamflows, and streamflow over the embankment, one-dimensional modeling cannot fully describe the streamflow paths. Elsewhere, abrupt changes in the channel cross sections cause large changes in channel conveyance, which increases uncertainty that energy losses are correctly computed (Davidian, 1984). Finally, because of the steepness of the channel, large drops in the water surface occur between cross sections bounding channel junctions, causing additional uncertainty.

The regional regression equations used to compute modeled streamflows also have uncertainties, especially in desert regions with shorter period datasets, highly variable peak streamflow, and zero streamflow years (Gotvald and others, 2012). These uncertainties grow with the lower probability of the streamflow's occurrence (the 4-percent AEP versus the 0.2 -percent AEP). The previously published regional regression equations used by Bowers (1989) have computed streamflows $10-50$ percent greater than Gotvald and others (2012), illustrating how the additional data collected indicates these issues.

Finally, the model does not address hazards related to gully and overland flow from the adjacent hillslopes. Currently, many gullies flow directly into building walls or spread onto parking lots with no established drainage. The erosion and deposition from these gullies and hillslopes was an important and possibly major cause of damage during the October 18, 2015, flood.

\section{Suggestions for Future Research}

Two crest-stage gages were installed at Scotty's Castle in December 2016, one approximately 1,600 ft upstream of the bridge in Grapevine Canyon and one approximately $1,700 \mathrm{ft}$ upstream of the confluence in Tie Canyon. Long-term monitoring of peak flows at the site would provide additional calibration data and the ability to perform site specific flood frequency analyses (10 years are the minimum required [England and others, 2018]), as well as provide data from currently unrepresented locations for regional flood frequency regression equations. However, as of September 2020, no streamflow has occurred at the two sites. 
Along with the two crest-stage gages, scour chains were installed in both canyons. Although the measured scour at those points cannot be assumed to apply to the entire reach, it can provide information on the relative importance of scour to the reach. If scour is found to be significant, additional scour chains could be installed in indirect measurement sections to help to reduce uncertainties associated with scour and fill during floods.

One-dimensional hydraulic models, such as the step-backwater method, assume straight streamflow and do not perform routing of streamflow. In locations such as Upper Tie Canyon, Lower Grapevine Canyon, and Upper Grapevine Canyon (upstream of the bridge), streamflow is mostly straight, and routing should not cause appreciable changes in the inundation locations. In the complex areas around the Tie and Grapevine Canyon confluence, the use of two-dimensional hydraulic models to determine flood-inundation areas would more accurately describe the complex streamflow paths. If channel modifications significant enough to be useful for flood protection are performed, the development of a two-dimensional model might provide more accurate flood-inundation area mapping.

\section{Summary and Conclusions}

This report provides a series of updated maps for the flood-inundation areas near Death Valley Scotty Historic District in Death Valley National Park. A terrestrial laser scanner (TLS) was used to collect elevation data to construct a digital terrain model (DTM) for the area. Topographic and structural data were derived from this DTM and used in a one-dimensional hydraulic model. Annual exceedance probability (AEP) streamflows were computed from regional regression equations and used with the hydraulic model to determine the water surface elevation for the floods. Finally, these water surfaces were mapped on the DTM to create flood-inundation maps.

Sections of Grapevine Canyon Road are subject to flooding by all the computed AEP floods. For all the computed AEP floods, two buildings at Scotty's Castle are also subject to flooding, but none of the modeled floods reached Scotty's Castle main building, although it still could be affected by gully and overflow flow from the nearby hillslopes. The bridge and embankment are subject to overtopping by the 2-percent AEP flood. Sensitivity analyses illustrate the bridge is sensitive to fill and vegetation growth, with overtopping occurring at the 4-percent AEP flood with pre-October 2015 flood conditions. All computed floods in Tie Canyon result in streamflow outside the main channel with the possibility of future floods moving the active main channel to the east of the gravel separator, closer to the bridge and embankment.
Specific uncertainties with the model are lack of model calibration, lack of a site-specific flood frequency analysis, the limitations of one-dimensional modeling, and uncertainties about the behavior of very steep gravel bed streams during floods. These uncertainties should be considered when viewing the results of this report.

\section{References Cited}

Aldridge, B.N., and Garrett, J.M., 1973, Roughness coefficients for stream channels in Arizona: U.S. Geological Survey Open File Report 73-3, 87 p., accessed November 12, 2015, at https://doi.org/10.3133/ofr733.

Arcement, G.J., Jr., and Schnieder, V.R., 1989, Guide for selecting Manning's roughness coefficients for natural channels and flood plains: U.S. Geological Survey Water-Supply Paper 2339, 38 p., accessed October 17, 2014, at https://doi.org/10.3133/wsp2339.

American Society for Photogrammetry and Remote Sensing, 2014, ASPRS positional accuracy standards for digital geospatial data, edition 1, version 1.0: Photogrammetric Engineering \& Remote Sensing, v. 81, no. 3, p. 1073-1085, accessed September 4, 2017, at https://www.asprs.org/newsresources/asprs-positional-accuracy-standards-for-digitalgeospatial-data

Barnes, H.H., Jr., 1967, Roughness characteristics for natural channels: U.S. Geological Survey Water-Supply Paper 1849, 213 p., https://doi.org/10.3133/wsp1849.

Bowers, J.C., 1989, Potential hazards from floodflows in Grapevine Canyon, Death Valley National Monument, California and Nevada: U.S. Geological Survey Water Resources Investigations Report 1989-4063, 19 p., 1 pl., accessed December 1, 2015, at https://doi.org/10.3133/wri894063.

Bray, D.I., and Davar, K.S., 1987, Resistance to flow in gravel-bed rivers: Canadian Journal of Civil Engineering, v. 14, no. 1, p. 77-86, accessed May 9, 2017, https://doi.org/10.1139/187-010.

Chow, V.T., 1959, Open-channel hydraulics: New York, McGraw-Hill, 680 p.

Collins, B.D., Corbett, S.C., Sankey, J.B., and Fairley, H.C., 2014, High-resolution topography and geomorphology of select archeological sites in Glen Canyon National Recreation Area, Arizona: U.S. Geological Survey Scientific Investigations Report 2014-5126, 31 p., accessed May 31, 2017, at https://doi.org/10.3133/sir20145126. 
Costa, J.E., and Jarrett, R.D., 2008, An evaluation of selected extraordinary floods in the United States reported by the U.S. Geological Survey and implications for future advancement of flood science: U.S. Geological Survey Scientific Investigations Report 2008-5164, 232 p., accessed February 21, 2016, at https://doi.org/10.3133/sir20085164.

Crippen, J.R., 1979, Potential hazards from floodflows and debris movement in the Furnace Creek area, Death Valley National Monument, California-Nevada: U.S. Geological Survey Open-File Report 79-991, 40 p., accessed December 1, 2015, at https://doi.org/10.3133/ofr79991.

Crippen, J.R., 1981, Potential hazards from floodflows in Wildrose Canyon, Death Valley National Monument, California-Nevada: U.S. Geological Survey Open-File Report 81-407, 23 p., accessed December 1, 2015, at https://doi.org/10.3133/ofr81407.

Davidian, J., 1984, Computation of water surface profiles in open channels: U.S. Geological Survey Techniques and Methods Report, book 11, chap. A15, 120 p., https://doi.org/10.3133/twri03A15.

England, J.F., Jr., Cohn, T.A., Faber, B.A., Stedinger, J.R., Thomas, W.O., Jr., Veilleux, A.G., Kiang, J.E., and Mason, R.R., Jr., 2018, Guidelines for determining flood flow frequency-Bulletin 17C: U.S. Geological Survey Techniques and Methods, book 4, chap. B5, 148 p., https://doi.org/10.3133/tm4B5.

Federal Emergency Management Agency, 2016, Guidance for flood risk analysis and mapping: elevation guidance, 21 p., accessed September 5, 2017, at https://www.fema.gov/media-library-data/1469794589266f404b39e73fa7a1c5ffe4447636634d4/Elevation_Guidance May_2016.pdf.

Gotvald, A.J., Barth, N.A., Veilleux, A.G., and Parrett, C., 2012, Methods for determining magnitude and frequency of floods in California, based on data through water year 2006: U.S. Geological Survey Scientific Investigations Report 2012-5113, 38 p., 1 pl., accessed May 9, 2017, at https://doi.org/10.3133/sir20125113.

Grant, G.E., 1997, Critical flow constrains flow hydraulics in mobile-bed streams-A new hypothesis: Water Resources Research, v. 33, no. 2, p. 349-358, accessed August 23, 2017, https://doi.org/10.1029/96WR03134.
Holmes, R.R., Jr., and Dinicola, K., 2010, 100-Year flood-it's all about chance: U.S. Geological Survey General Information Report 106, 1 p., https://doi.org/10.3133/gip106.

Hooke, J.M., and Mant, J.M., 2000, Geomorphological impacts of a flood event on ephemeral channels in SE Spain: Geomorphology, v. 34, no. 3-4, p. 163-180, accessed May 10, 2017, https://doi.org/10.1016/S0169-555X(00)00005-2.

Jarrett, R.D., 1984, Hydraulics of high-gradient streams: Journal of Hydraulic Engineering, v. 110, no. 11, p. 1519-1539, accessed May 15, 2017, https://doi.org/ 10.1061/(ASCE)0733-9429(1984)110:11(1519).

Limerinos, J.T., 1970, Determination of Manning coefficient from measured bed roughness in natural channels: U.S. Geological Survey Water Supply Paper 1898-B, 47 p., accessed May 9, 2017, at https://doi.org/10.3133/wsp1898B.

Marcus, W., Roberts, K., Harvey, L., and Tackman, G., 1992, An evaluation of methods for estimating Manning's $\mathrm{n}$ in small mountain streams: Mountain Research and Development, v. 12, no. 3, p. 227-239, accessed August 23, 2017, https://doi.org/10.2307/3673667.

Miller, G.A., 1977, Appraisal of the water resources of Death Valley, California-Nevada: U.S. Geological Survey Open File Report 77-728, 68 p., accessed December 18, 2015, at https://doi.org/10.3133/ofr77728.

Morris, C.M., Welborn, T.L., and Minear, J.T., 2020, Geospatial Data: California, Tabular Data, and Surface-Water Model Archive for Delineation of Flood-Inundation Areas in Grapevine Canyon Near Scotty's Castle, Death Valley National Park, https://doi.org/10.5066/P9IPKW55.

National Park Service, 2016, Park proposes fee changes; Most funds to be used to restore Scotty's Castle: National Park Service web page, accessed at January 17, 2017, at https://parkplanning.nps.gov/document.cfm? documentID $=73064$.

National Research Council, 1996, Alluvial fan flooding: Washington, D.C., National Academies Press, accessed March 10, 2017, at https:/doi.org/10.17226/5364.

National Weather Service, 2015, October 2015 flash flooding \& storms: National Weather Service web page, accessed December 10, 2015, at https://www.wrh.noaa.gov/vef/ projects/201510_stormevents.pdf. 
Overzet, D., Brunson, R.F., and Greslin, R., 1983, Baseline floodplain analysis-Death Valley flood studies: National Park Service, Flood Mitigation Studies Package 271, 366 p., accessed January 12, 2016, at https://irma.nps.gov/DataStore/DownloadFile/462266.

Phillips, J.V., and Ingersoll, T.L., 1998, Verification of roughness coefficients for selected natural and constructed stream channels in Arizona: U.S. Geological Survey Professional Paper 1585, 77 p., https://doi.org/10.3133/pp1584.

Powell, D.M., Brazier, R., Parsons, A., Wainwright, J., and Nichols, M., 2007, Sediment transfer and storage in dryland headwater streams: Geomorphology, v. 88 , no. 1-2, p. 152-166, accessed May 10, 2017, https://doi.org/10.1016/j.geomorph.2006.11.001.

Rickenmann, D., and Recking, A., 2011, Evaluation of flow resistance in gravel-bed rivers through a large field data set: Water Resources Research, v. 47, no. 7, p. 1-22, accessed June 12, 2017, https://doi.org/10.1029/2010WR009793.

Rydlund, P.H., Jr., and Densmore, B.K., 2012, Methods of practice and guidelines for using survey-grade global navigation satellite systems (GNSS) to establish vertical datum in the United States Geological Survey: U.S. Geological Survey Techniques and Methods Report, book 11, chap. D1, $120 \mathrm{p}$. with appendixes, accessed February 12, 2016, at https://doi.org/10.3133/tm11D1.

U.S. Army Corps of Engineers, 2019, Hydrologic Engineering Center River Analysis System (version 5.0.7): U.S. Army Corps of Engineers, accessed at https:/www.hec.usace.army.mil/software/hec-ras/.
U.S. Army Corps of Engineers, 2015, Hydrologic Engineering Center Geo River Analysis System (version 10.3): U.S. Army Corps of Engineers, accessed January 12, 2017, at https://www.hec.usace.army.mil/software/hec-georas/.

U.S. Geological Survey, 2018a, USGS 10250800 Darwin Wash NR Darwin, CA, in USGS water data for the Nation: U.S. Geological Survey National Water Information System database, accessed July 30, 2018, at https://doi.org/10.5066/F7P55KJN. [Site information directly accessible at https://waterdata.usgs.gov/nwis/ inventory?agency_code $=$ USGS\&site_no $=10250800$.]

U.S. Geological Survey, 2018b, USGS 10251100 Salt C NR Stovepipe Wells, CA, in USGS water data for the Nation: U.S. Geological Survey National Water Information System database, accessed July 30, 2018, at https://doi.org/10.5066/F7P55KJN. [Site information directly accessible at https://waterdata.usgs.gov/nwis/ inventory?agency_code=USGS\&site_no=10251100.]

Waananen, A.O., 1971, Floods from small drainage areas in California; A compilation of peak data, October 1958 to September 1970: U.S. Geological Survey Open-File Report 71-313, 134 p., accessed January 13, 2017, at https://doi.org/10.3133/ofr71313.

Wolman, M.G., 1954, A method of sampling coarse river-bed material: Transactions American Geological Union, v. 35, no. 6, p. 951-956, accessed March 1, 2017, https://doi.org/10.1029/TR035i006p00951. 

For more information concerning the research in this report, contact the Nevada Water Science Center

U.S. Geological Survey

2730 N. Deer Run Road

Carson City, Nevada 95819

https://www.usgs.gov/centers/nv-water

Publishing support provided by the U.S. Geological Survey

Science Publishing Network, Sacramento Publishing Service Center 


\section{$\frac{\mathbb{2}}{3}$}

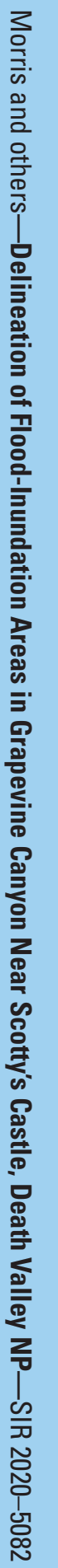

